University of Nebraska - Lincoln

DigitalCommons@University of Nebraska - Lincoln

\title{
Relative contributions of animal and muscle effects to variation in beef lean color stability
}

D. A. King

USDA-ARS, andy.king@usda.gov

S. D. Shackelford

USDA-ARS

T. L. Wheeler

USDA-ARS, tommy.wheeler@ars.usda.gov

Follow this and additional works at: https://digitalcommons.unl.edu/usdaarsfacpub

Part of the Agricultural Science Commons

King, D. A.; Shackelford, S. D.; and Wheeler, T. L., "Relative contributions of animal and muscle effects to variation in beef lean color stability" (2011). Publications from USDA-ARS / UNL Faculty. 707.

https://digitalcommons.unl.edu/usdaarsfacpub/707

This Article is brought to you for free and open access by the U.S. Department of Agriculture: Agricultural Research Service, Lincoln, Nebraska at DigitalCommons@University of Nebraska - Lincoln. It has been accepted for inclusion in Publications from USDA-ARS / UNL Faculty by an authorized administrator of DigitalCommons@University of Nebraska - Lincoln. 


\title{
JOURNAL OF ANIMAL SCIENCE
}

The Premier Journal and Leading Source of New Knowledge and Perspective in Animal Science

\section{Relative contributions of animal and muscle effects to variation in beef lean color stability}

\author{
D. A. King, S. D. Shackelford and T. L. Wheeler
}

J Anim Sci 2011.89:1434-1451.

doi: 10.2527/jas.2010-3595 originally published online Dec 23, 2010;

The online version of this article, along with updated information and services, is located on the World Wide Web at:

http://jas.fass.org/cgi/content/full/89/5/1434 


\title{
Relative contributions of animal and muscle effects to variation in beef lean color stability ${ }^{1,2}$
}

\author{
D. A. King, ${ }^{3}$ S. D. Shackelford, and T. L. Wheeler \\ USDA, Agricultural Research Service, Roman L. Hruska US Meat Animal Research Center, \\ Meat Safety and Quality Research Unit, Clay Center, NE 68933-0166
}

\begin{abstract}
Muscles from beef carcasses $(\mathrm{n}=100)$ were selected from a commercial processor and aged for $14 \mathrm{~d}$. Longissimus lumborum (LL), semimembranosus (SM), biceps femoris (BF), gluteus medius (GM), triceps brachii (TB), rectus femoris, vastus lateralis, adductor, semitendinosus, infraspinatus, teres major, biceps femoris ischiatic head, biceps femoris sirloin cap, and gracillus steaks were placed in display for 9 d. Instrumental color variables [lightness $\left(\mathrm{L}^{*}\right)$, redness $\left(a^{*}\right)$, yellowness $\left(b^{*}\right)$, hue angle, chroma, and overall color change from $\mathrm{d} 0(\Delta \mathrm{E})$ ] were determined on $\mathrm{d}$ $0,1,3,6$, and 9 of display. Muscle $\mathrm{pH}$ and myoglobin content were determined for LL, SM, BF, GM, and TB. Muscles differed $(P<0.05)$ in initial values of each color variable evaluated, and the extent and timing of changes during display differed across muscles. Relationships between color variables measured in LL steaks and those measured in steaks from other muscles differed across days of display with the strongest relationships being observed earlier in the display period for labile muscles and later in stable muscles. Lightness of LL steaks was correlated with lightness of all of other muscles evaluated, regardless of display day $(\mathrm{r}=0.27$ to 0.79 ). For $\mathrm{a}^{*}$, hue angle, chroma, and $\Delta \mathrm{E}$ values, the
\end{abstract}

strongest relationships between LL values and those of other muscles were detected between d $9 \mathrm{LL}$ values and those of other muscles on $\mathrm{d} 3,6$, or 9 , depending on the relative stability of the muscle. Correlation coefficients between $\mathrm{d} 9 \mathrm{a}^{*}$, hue angle, chroma, and $\Delta \mathrm{E}$ values in LL and those of other muscles were $0.50,0.65,0.28$, and $0.43(P<0.05)$ or greater, respectively, for the muscles included in the study. Myoglobin content of SM, BF, GM, and TB was highly correlated with that of LL ( $\mathrm{r}$ $=0.83,0.82,0.72$, and 0.67, respectively; $P<0.05$ ). Muscle $\mathrm{pH}$ of LL was correlated with $\mathrm{pH}$ of $\mathrm{SM}$ and GM $(\mathrm{r}=0.44$ and $0.53 ; P<0.05)$, but not $(P>0.05)$ $\mathrm{pH}$ of $\mathrm{BF}$ or TB. Muscle effects generally explained more variation in $\mathrm{a}^{*}, \mathrm{~b}^{*}$, hue angle, chroma, and $\Delta \mathrm{E}$ than animal effects. However, the relative importance of animal effects increased as display continued. These data indicate that animal effects were consistent across muscles, though muscle effects had greater contribution to color stability variation. Furthermore, strong relationships between LL color stability and the stability of other muscles indicate that strategies developed to manage animal variation in LL color stability would beneficially affect the entire carcass.

Key words: beef, color stability, meat color, muscle

(02011 American Society of Animal Science. All rights reserved.

J. Anim. Sci. 2011. 89:1434-1451

doi:10.2527/jas.2010-3595

\section{INTRODUCTION}

Industry sources indicate that some carcasses produce cuts with insufficient color life for case-ready product lines, resulting in significant losses to the in-

\footnotetext{
${ }^{1}$ Mention of trade names or commercial products in this publication is solely for the purpose of providing specific information and does not imply recommendation or endorsement by the USDA. The authors are grateful to Patty Beska, Kathy Mihm, Kristen Ostdiek, and Pat Tammen of the US Meat Animal Research Center for their assistance in the execution of this experiment and to Marilyn Bierman of the US Meat Animal Research Center for her secretarial assistance.

${ }^{2}$ USDA is an equal opportunity provider and employer.

${ }^{3}$ Corresponding author: andy.king@ars.usda.gov

Received October 12, 2010.

Accepted December 21, 2010.
} dustry. Some investigators have concluded that animal effects are of lesser importance as a source of variation in color stability compared with effects such as muscles within a carcass or storage temperature (Hood, 1980; Renerre and Labas, 1987), and few investigations have addressed animal variation in color stability. Thus, color stability research has focused on differences due to ante- or postmortem management (Ledward, 1985; Lawrence et al., 2004; Mancini et al., 2008) and across muscles (Talmant and Monin, 1986; McKenna et al., 
2005). However, previous work from our laboratory has substantiated the importance of animal variation and indicated that genetic influences contribute to animal variation in lean color stability (King et al., 2010).

Inherent muscle metabolic characteristics such as pigment concentration, mitochondrial oxygen consumption, and reducing capacity through enzymatic and nonenzymatic mechanisms have been implicated in regulating color stability (O'Keefe and Hood, 1982; Faustman and Cassens, 1990; Bekhit and Faustman, 2005; Mancini and Hunt, 2005). It is understood that environmental factors such as chilling rate, storage temperature, and microbial load have profound effects on color stability. Furthermore, it is well understood that these factors differ among muscles within a carcass (Sammel et al., 2002; McKenna et al., 2005; Seyfert et al., 2006).

However, given the evidence that these factors also vary substantially within the LM and contribute to variation in color stability in the LM (King et al., 2010, 2011), it appears that significant opportunity exists to use genetic selection and management to reduce animal variation in color stability. The present experiment was conducted to characterize the relative contribution of animal and muscle effects to beef lean color stability. Moreover, we attempted to determine the extent to which technologies designed to reduce animal variation in LM lean color stability would affect other muscles from the carcass.

\section{MATERIALS AND METHODS}

Animal care and use approval was not obtained for this study because the samples were obtained from a federally inspected slaughter facility.

Carcasses $(\mathrm{n}=100)$ were selected on $5 \mathrm{~d}$ (selection days were approximately 2 wk apart) from a commercial processing facility as they were presented for grading. All carcasses had been chilled for $48 \mathrm{~h}$ before grading (i.e., no weekend chilled carcasses were sampled). Carcasses were selected across numerous production lots to represent US Choice and Select grade groups, and, as part of a concurrent experiment, were selected to be extremely tender or extremely tough according the US Meat Animal Research Center (USMARC) noninvasive tenderness prediction system (Shackelford et al., 2005), but otherwise varied widely with regard to carcass cutability factors. During fabrication, the strip loin [Institutional Meat Purchase Specification (IMPS) \#180; USDA, 1996; NAMP, 2003], top sirloin butt (IMPS \#184), inside round (IMPS \#168), knuckle (IMPS \#167), gooseneck round (IMPS \#170), and shoulder clod (IMPS \#114) were retrieved and transported, under refrigeration to USMARC. Individual muscles were removed from each subprimal as follows: longissimus lumborum (LL) from the striploin; gluteus medius (GM) and biceps femoris, sirloin cap (BFSC) from the top sirloin butt; semimembranosus (SM), adductor (AD), and gracillus (GR) from the inside round; vastus lateralis (VL) and rectus femoris
(RF) from the knuckle; biceps femoris (BF), biceps femoris, ischiatic head (BFIH), and semitendinosus (SN) from the gooseneck round; and triceps brachii (TB), infraspinatus (IS), and teres major (TM) from the shoulder clod. All muscles were separated along natural seams, and fat in excess of $0.3 \mathrm{~cm}$ was removed. Muscles were vacuum packaged and stored $\left(1^{\circ} \mathrm{C}\right)$ until $14 \mathrm{~d}$ postmortem. After aging, steaks $(2.54 \mathrm{~cm})$ were cut perpendicular to the long axis of each cut. One steak was removed from the center portion of each cut for use in the present experiment.

Steaks were placed on polystyrene trays with soaker pads and overwrapped with oxygen-permeable polyvinylchloride (PVC) film [stretchable meat film 55003815; Prime Source, St. Louis, MO; oxygen transmission rate $=1.4 \mathrm{~mL} /\left(\mathrm{cm}^{2} \cdot 24 \mathrm{~h}\right)$ at $\left.23^{\circ} \mathrm{C}\right]$. Steaks were placed under continuous fluorescent lighting (color temperature $=3,500 \mathrm{~K}$; color rendering index $=86 ; 32 \mathrm{~W}$; T8 Ecolux bulb, model number F32T8/SPX35 GE, GE Lighting, Cleveland, OH). Light intensity at the meat surface was approximately 2,000 lx. Display was conducted in a refrigerated room $\left(1^{\circ} \mathrm{C}\right)$, and no temperature fluctuations associated with defrost cycles were encountered.

Steaks were allowed to bloom for at least $2 \mathrm{~h}$ after being packaged in the retail package before color measurement began. Instrumental color readings were taken on each steak on d 0, 1, 3, 6, and 9 using a Hunter Miniscan XE Plus colorimeter (HunterLab, Reston, VA) with a $25-\mathrm{mm}$ port. The number of readings taken on each steak was as follows: 5 from the SM, 4 from the BF, 3 from the GM and TB, and 2 from the LL, RF, VL, AD, SN, IS, TM, BFIH, BFSC, and GR. The colorimeter was set to collect spectral data with Illuminant A and a $10^{\circ}$ observer. The CIE L* (lightness), $\mathbf{a}^{*}$ (redness), and b* (yellowness) color-space values were reported as the average of the readings taken on each steak. Chroma (color intensity; also known as saturation index) was calculated as $\left[\left(\mathrm{a}^{* 2}+\mathrm{b}^{* 2}\right)^{0.5}\right]$. Hue angle (redness) was calculated as [arctangent $\left.\left(\mathrm{b}^{*} / \mathrm{a}^{*}\right) \times 180 / 3.142\right]$. Overall color change $(\Delta \mathbf{E})$ was calculated as: $\left[\left(\Delta \mathrm{L}^{* 2}+\Delta \mathrm{a}^{* 2}+\right.\right.$ $\left.\Delta \mathrm{b}^{* 2}\right)^{0.5}$, where $\Delta \mathrm{L}^{*}, \Delta \mathrm{a} *$, and $\Delta \mathrm{b}^{*}$ are the difference between $\mathrm{d} 0$ and $\mathrm{d} 1,3,6$, and 9 values for $\mathrm{L}^{*}$, $\mathrm{a}^{*}$, and $b^{*}$, respectively.

\section{pH and Myoglobin Concentration}

After display, LL, SM, BF, GM, and TB steaks which were reserved for determination of $\mathrm{pH}$ and myoglobin concentration, were trimmed free of external fat and epimysium, diced, and pulverized in liquid nitrogen to produce a homogenous powder. Muscle $\mathrm{pH}$ was determined as prescribed by Bendall (1973). Duplicate 2.5-g samples were homogenized in 10 volumes of a $5 \mathrm{mM}$ iodoacetate, $150 \mathrm{mM} \mathrm{KCl}$ solution $(\mathrm{pH}=7.0)$. Homogenates were allowed to rest for a minimum of $1 \mathrm{~h}$ at room temperature, mixed via vortexing, and $\mathrm{pH}$ was measured using a semi-micro combination electrode (Corning Inc., Corning, NY) attached to a Corning 125 $\mathrm{pH}$ meter. 
Table 1. Least squares means for lightness $\left(\mathrm{L}^{*}\right)$ values of steaks from 14 beef muscles placed in simulated retail display for $9 \mathrm{~d}$

\begin{tabular}{|c|c|c|c|c|c|}
\hline Semimembranosus & $43.8^{\mathrm{de}, \mathrm{z}}$ & $42.9^{\text {de, } y}$ & $41.6^{\mathrm{fg}, \mathrm{x}}$ & $41.2^{\mathrm{g}, \mathrm{w}}$ & $41.3^{\mathrm{d}, \mathrm{wx}}$ \\
\hline Gluteus medius & $45.4^{\mathrm{c}, \mathrm{z}}$ & $43.6^{\mathrm{cd}, \mathrm{y}}$ & $42.1^{\mathrm{ef}, \mathrm{y}}$ & $41.6^{\mathrm{g}, \mathrm{wx}}$ & $41.8^{\mathrm{d}, \mathrm{w}}$ \\
\hline Triceps brachii & $42.7^{\mathrm{f}, \mathrm{z}}$ & $41.3^{\mathrm{f}, \mathrm{y}}$ & $40.1^{\mathrm{h}, \mathrm{x}}$ & $39.9^{\mathrm{ef}, \mathrm{w}}$ & $39.5^{\mathrm{f,w}}$ \\
\hline Rectus femoris & $46.7^{\mathrm{b}, \mathrm{z}}$ & $44.7^{\mathrm{b}, \mathrm{y}}$ & $44.5^{\mathrm{c}, \mathrm{y}}$ & $44.3^{\mathrm{h}, \mathrm{xy}}$ & $44.0^{c, x}$ \\
\hline Adductor & $44.8^{\mathrm{cd}, \mathrm{z}}$ & $42.5^{\mathrm{e}, \mathrm{y}}$ & $42.0^{\mathrm{f}, \mathrm{xy}}$ & $42.1^{\mathrm{efg}, \mathrm{x}}$ & $41.8^{\mathrm{d}, \mathrm{x}}$ \\
\hline Infraspinatus & $47.2^{\mathrm{b}, \mathrm{z}}$ & $46.4^{\mathrm{a}, \mathrm{y}}$ & $46.9^{\mathrm{b}, \mathrm{x}}$ & $46.8^{\mathrm{b}, \mathrm{x}}$ & $46.3^{\mathrm{b}, \mathrm{w}}$ \\
\hline Teres major & $46.5^{\mathrm{b}, \mathrm{z}}$ & $44.2^{\mathrm{bc}, \mathrm{y}}$ & $44.3^{\mathrm{c}, \mathrm{x}}$ & $43.8^{\mathrm{cd}, \mathrm{x}}$ & $41.9^{\mathrm{d}, \mathrm{w}}$ \\
\hline Biceps femoris ischiatic head & $45.3^{\mathrm{c}, \mathrm{z}}$ & $43.6^{\mathrm{cd}, \mathrm{y}}$ & $43.8^{\mathrm{cd}, \mathrm{x}}$ & $42.9^{\mathrm{de}, \mathrm{x}}$ & $42.0^{\mathrm{d}, \mathrm{w}}$ \\
\hline Biceps femoris sirloin cap & $43.3^{\mathrm{ef}, \mathrm{z}}$ & $41.1^{\mathrm{f}, \mathrm{x}}$ & $40.5^{\mathrm{gh}, \mathrm{w}}$ & $42.0^{\mathrm{efg}, y}$ & $40.0^{\mathrm{ef,v}}$ \\
\hline Gracillus & $41.1^{\mathrm{g}, \mathrm{z}}$ & $40.3^{\mathrm{f}, \mathrm{y}}$ & $39.7^{\mathrm{h}, \mathrm{x}}$ & $39.6^{\mathrm{h}, \mathrm{x}}$ & $37.2^{\mathrm{g}, \mathrm{w}}$ \\
\hline
\end{tabular}

${ }^{\mathrm{a}-\mathrm{h}}$ Within a column, least squares means lacking common superscripts differ $(P<0.05)$.

${ }^{\mathrm{v}-\mathrm{Z}}$ Within a row, least squares means lacking common superscripts differ $(P<0.05)$.

Myoglobin was extracted and quantified following the method described by Warriss (1979) as modified by Hunt et al. (1999). Briefly, duplicate 2.5-g samples were homogenized in 10 volumes of $40 \mathrm{~m} M$ potassium phosphate buffer $(\mathrm{pH}=6.8)$. Homogenates were held, on ice, for $1 \mathrm{~h}$ to allow complete pigment extraction before centrifugation $(15,000 \times g)$ for $30 \mathrm{~min}$ at $4^{\circ} \mathrm{C}$. Supernatant $(1.5 \mathrm{~mL}$ ) was syringe filtered (Nalgene $0.45 \mu \mathrm{m}$, surfactant-free cellulose acetate membrane, Thermo Fisher Scientific, Rochester, NY) into a 4-mL cuvette with $1 \mathrm{~mL}$ of $40 \mathrm{~m} M$ phosphate buffer and $0.5 \mathrm{~mL}$ of sodium hydrosulfite $(10 \mathrm{mg} / \mathrm{mL})$. Absorbance spectra from 400 to $700 \mathrm{~nm}$ were scanned on each sample using a DU 640 spectrophotometer (Beckman Coulter Inc., Fullerton, CA). Once samples were verified to be in the reduced state (absorbance peak within $2 \mathrm{~nm}$ of 433), extracted pigment concentration was calculated using the absorbance at $433 \mathrm{~nm}$, a molar extinction coefficient of $114,000 \mathrm{M}^{-1} \mathrm{~cm}^{-1}$, the molecular weight of myoglobin $(16,800)$, and the appropriate dilution factor.

\section{Statistical Analysis}

Muscle effects on display data were analyzed as a randomized complete block with repeated measures using the PROC MIXED procedure (SAS Inst. Inc., Cary, NC). The model included fixed effects of quality grade, muscle, and day of display, and selection day as a random effect. Quality grade was not a source of variation for any of the color variables included in the study and was removed from the model. Day of display was treated as a repeated effect with a subject of muscle within carcass and an unstructured covariance structure. Means for significant effects were separated using the DIFF option. To aid in interpretation of muscle $\times$ day of display interactions, simple effects were tested using the slice option on the LSMEANS statement, and when significant, simple effects were separated rather than all possible comparisons. Muscle effects on myoglobin and $\mathrm{pH}$ data were analyzed using a PROC MIXED model with muscle as a fixed effect and selection day as a random effect. Least squares means were generated and separated as described above.

Correlation analysis (PROC CORR procedure of SAS) was used to test relationships between color variables measured on LL steaks and those measured on the other muscles evaluated in the study. Because muscles discolored at differing rates, correlation coefficients were generated comparing values collected on individual muscles on all days of display to those collected on LL all days of display. Variance component analysis was conducted using the PROC VARCOMP procedure of SAS using a model that included selection day, quality grade, animal, muscle, and residual. Data from each day of display were analyzed independently.

\section{RESULTS AND DISCUSSION}

\section{Muscle Differences During Display}

All color change variables investigated in this study were affected by a muscle $\times$ display day interaction $(P$ $<0.05)$. To simplify interpretation of this large, complex interaction, mean separation was conducted for simple effects of display day within each muscle and muscle effects within each display day. In most muscles, $\mathrm{L}^{*}$ decreased $(P<0.05)$ as display progressed, though these changes were generally small (Table 1 ). In most muscles, the largest declines were detected between $\mathrm{d}$ 0 and 3 , with $\mathrm{L}^{*}$ values either not changing or changing very little between $d 3$ and 9 . Regardless of display day, SN had the lightest (greatest $L^{*}$ values: $P<0.05$ ) colored steaks, whereas GR had the darkest colored steaks $(P<0.05)$.

In most of the muscles evaluated in this study, a* values decreased $(P<0.05)$ progressively as display 
Table 2. Least squares means for redness $\left(a^{*}\right)$ values of steaks from 14 beef muscles placed in simulated retail display for $9 \mathrm{~d}$

\begin{tabular}{|c|c|c|c|c|c|}
\hline Muscle & Day 0 & Day 1 & Day 3 & Day 6 & Day 9 \\
\hline Longissimus lumborum & $32.8^{\text {def,z }}$ & $33.1^{\mathrm{a}, \mathrm{z}}$ & $30.7^{\mathrm{a}, \mathrm{y}}$ & $26.6^{\mathrm{a}, \mathrm{x}}$ & $19.6^{\mathrm{a}, \mathrm{w}}$ \\
\hline Semimembranosus & $34.5^{\mathrm{a}, \mathrm{z}}$ & $33.2^{\mathrm{a}, \mathrm{y}}$ & $29.4^{\mathrm{b}, \mathrm{x}}$ & $23.7^{\mathrm{b}, \mathrm{w}}$ & $17.2^{\mathrm{b}, \mathrm{v}}$ \\
\hline Biceps femoris & $34.7^{\mathrm{a}, \mathrm{z}}$ & $32.8^{\mathrm{a}, \mathrm{y}}$ & $28.6^{\mathrm{c}, \mathrm{x}}$ & $20.9^{\mathrm{de}, \mathrm{w}}$ & $13.1^{\text {fgh,v }}$ \\
\hline Gluteus medius & $34.1^{\mathrm{ab}, \mathrm{z}}$ & $31.8^{\mathrm{bc}, \mathrm{y}}$ & $26.6^{\mathrm{de}, \mathrm{x}}$ & $19.8^{\mathrm{ef}, \mathrm{w}}$ & $13.6^{\mathrm{efg}, \mathrm{v}}$ \\
\hline Triceps brachii & $33.0^{\mathrm{cd}, \mathrm{z}}$ & $31.5^{\mathrm{cd}, \mathrm{y}}$ & $26.8^{\mathrm{d}, \mathrm{x}}$ & $19.9^{\mathrm{def}, \mathrm{w}}$ & $13.7^{\text {efg,v }}$ \\
\hline Rectus femoris & $33.0^{\text {cde }, z}$ & $30.9^{\mathrm{de}, \mathrm{y}}$ & $24.9^{\mathrm{f}, \mathrm{x}}$ & $17.6^{\mathrm{gh}, \mathrm{w}}$ & $13.1^{\text {fgh,v }}$ \\
\hline Vastus lateralis & $33.6^{\mathrm{bc}, \mathrm{z}}$ & $30.7^{\mathrm{e}, \mathrm{y}}$ & $24.5^{\mathrm{f}, \mathrm{x}}$ & $15.1^{\mathrm{i}, \mathrm{w}}$ & $12.3^{\text {hi,v }}$ \\
\hline Semitendinosus & $32.3^{\mathrm{fg}, \mathrm{z}}$ & $32.1^{\mathrm{b}, \mathrm{z}}$ & $27.9^{\mathrm{c}, \mathrm{y}}$ & $22.7^{\mathrm{bc}, \mathrm{x}}$ & $16.6^{\mathrm{bc}, \mathrm{w}}$ \\
\hline Adductor & $33.8^{\mathrm{b}, \mathrm{z}}$ & $31.1^{\text {de,y }}$ & $24.4^{\mathrm{f}, \mathrm{x}}$ & $16.1^{\mathrm{hi}, \mathrm{w}}$ & $12.2^{\mathrm{hi}, \mathrm{v}}$ \\
\hline Infraspinatus & $28.0^{\mathrm{j}, \mathrm{z}}$ & $28.1^{\mathrm{h}, \mathrm{z}}$ & $24.2^{\mathrm{f}, \mathrm{y}}$ & $18.7^{\mathrm{fg}, \mathrm{x}}$ & $13.9^{\mathrm{ef}, \mathrm{w}}$ \\
\hline Teres major & $30.8^{\mathrm{h}, \mathrm{z}}$ & $29.9^{\mathrm{f}, \mathrm{y}}$ & $24.2^{\mathrm{f}, \mathrm{x}}$ & $15.8^{\mathrm{i}, \mathrm{w}}$ & $15.6^{\mathrm{cd}, \mathrm{w}}$ \\
\hline Biceps femoris ischiatic head & $32.0^{\mathrm{g}, \mathrm{z}}$ & $33.2^{\mathrm{a}, \mathrm{y}}$ & $29.9^{\mathrm{b}, \mathrm{x}}$ & $22.0^{\mathrm{cd}, \mathrm{w}}$ & $14.5^{\mathrm{de}, \mathrm{v}}$ \\
\hline Biceps femoris sirloin cap & $32.4^{\mathrm{efg}, \mathrm{z}}$ & $29.0^{\mathrm{g}, \mathrm{y}}$ & $21.5^{\mathrm{g}, \mathrm{x}}$ & $10.7^{\mathrm{j}, \mathrm{w}}$ & $11.7^{\mathrm{i}, \mathrm{vw}}$ \\
\hline Gracillus & $29.8^{\mathrm{i}, \mathrm{z}}$ & $30.0^{\mathrm{f}, \mathrm{z}}$ & $25.9^{\mathrm{e}, \mathrm{y}}$ & $16.5^{\text {hi,x }}$ & $12.5^{\mathrm{ghi}, \mathrm{w}}$ \\
\hline SEM & 0.44 & & & & \\
\hline$P>\mathrm{F}$ & $<0.001$ & & & & \\
\hline
\end{tabular}

${ }^{\mathrm{a}-\mathrm{i}}$ Within a column, least squares means lacking common superscripts differ $(P<0.05)$.

${ }^{\mathrm{v}-\mathrm{Z}}$ Within a row, least squares means lacking common superscripts differ $(P<0.05)$.

increased (Table 2), though the timing and extent of these changes differed across muscles. On d 0, LL had smaller $(P<0.05)$ a* $^{*}$ values than $\mathrm{BF}$, SM, GM, AD, and VL. But by d 1, the LL was similar to the SM, $\mathrm{BF}$, and the $\mathrm{BFIH}$, which had greater a* values than all other muscles. On d 3,6, and 9, the LL had greater $a^{*}$ values than all other muscles evaluated in the study. The BFSC had the greatest decreases in $a^{*}$ and on $\mathrm{d} 6$ and 9 had the least $\mathrm{a}^{*}$ values of the muscles included in the study (Table 2).

As with $a^{*}$, muscles differed in rate and extent of change in $b^{*}$. In all muscles, $b^{*}$ decreased over the course of display, though LL, IS, BFSC, and GR steaks had modest increases $(P<0.05)$ in $\mathrm{b}^{*}$ values between d 0 and 1 before declining through the remainder of display (Table 3). Furthermore, SM, TB, and SN did not change $(P>0.05)$ in $\mathrm{b}^{*}$ during the first $24 \mathrm{~h}$ of display.

Hue angle increased $(P<0.05)$ incrementally as time in display increased for all muscles except BFSC and TM, in which hue angle decreased $(P<0.05)$ between d 6 and 9 (Table 4). As noted for $\mathrm{a}^{*}$ values, hue angle indicated that $\mathrm{a}^{*}$ was as great or greater in LL steaks at the end of display when compared with all other muscles included in the study. The BFSC, AD, and VL had the most dramatic increase in hue angles and, thus, had the least red hue on d 9 of display of the muscles included in this experiment.

Color intensity decreased during display as evidenced by reductions $(P<0.05)$ in chroma values (Table 5$)$. In most muscles, chroma values decreased with each increase in display time evaluated in this study. However,

Table 3. Least squares means for yellowness $\left(b^{*}\right)$ values of steaks from 14 beef muscles placed in simulated retail display for $9 \mathrm{~d}$

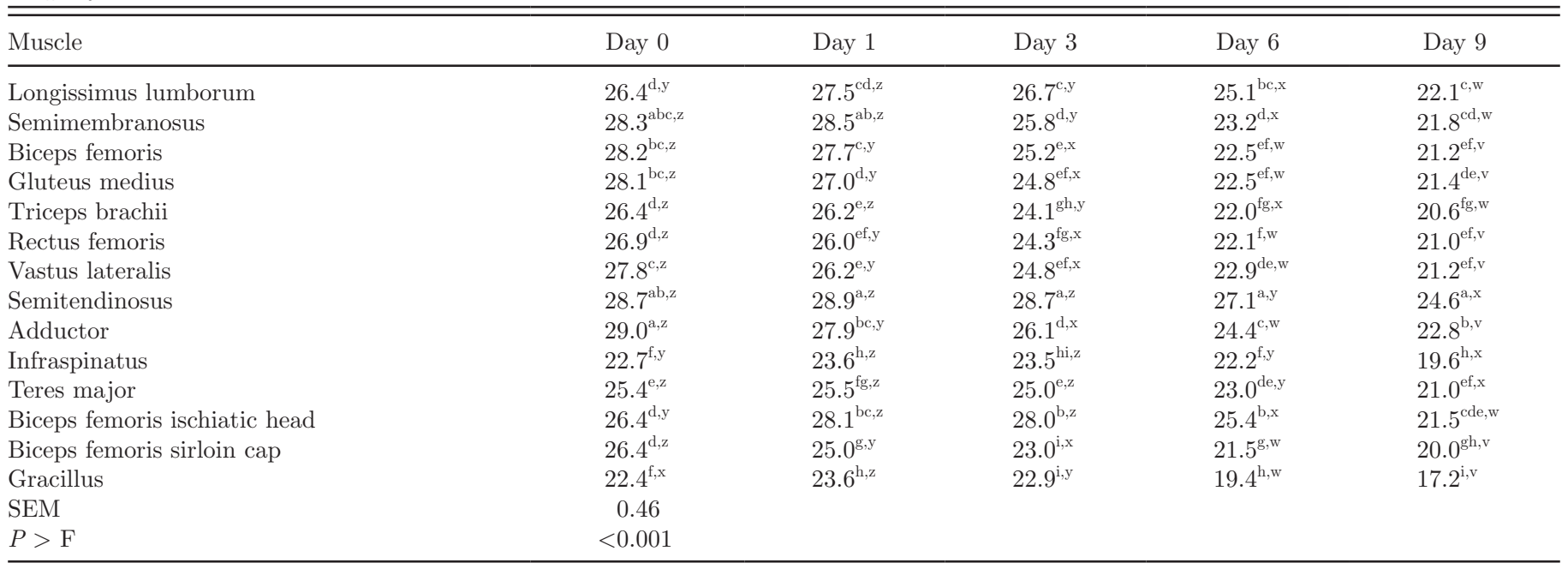

${ }^{\mathrm{a}-\mathrm{i}}$ Within a column, least squares means lacking common superscripts differ $(P<0.05)$.

${ }^{\mathrm{v}-\mathrm{Z}}$ Within a row, least squares means lacking common superscripts $\operatorname{differ}(P<0.05)$. 
Table 4. Least squares means for hue angle values of steaks from 14 beef muscles placed in simulated retail display for $9 \mathrm{~d}$

\begin{tabular}{|c|c|c|c|c|c|}
\hline Muscle & Day 0 & Day 1 & Day 3 & Day 6 & Day 9 \\
\hline Longissimus lumborum & $38.7^{\mathrm{gh}, \mathrm{z}}$ & $39.7^{\mathrm{e}, \mathrm{y}}$ & $41.0^{\mathrm{f}, \mathrm{x}}$ & $43.8^{\mathrm{g}, \mathrm{w}}$ & $49.7^{\mathrm{g}, \mathrm{v}}$ \\
\hline Semimembranosus & $39.3^{\text {cde,z }}$ & $40.6^{\mathrm{bc}, \mathrm{y}}$ & $41.3^{\mathrm{ef}, \mathrm{x}}$ & $44.9^{\mathrm{f}, \mathrm{w}}$ & $52.9^{\mathrm{f}, \mathrm{v}}$ \\
\hline Biceps femoris & $39.1^{\mathrm{ef}, \mathrm{z}}$ & $40.2^{\text {bcde, } y}$ & $41.5^{\mathrm{ef}, \mathrm{x}}$ & $47.7^{\mathrm{f}, \mathrm{w}}$ & $58.8^{\mathrm{bc}, \mathrm{v}}$ \\
\hline Gluteus medius & $39.3^{\text {cde,z }}$ & $40.3^{\text {bcd,y }}$ & $43.1^{\mathrm{d}, \mathrm{x}}$ & $49.2^{\mathrm{ef}, \mathrm{w}}$ & $57.9^{\mathrm{bcd}, \mathrm{v}}$ \\
\hline Triceps brachii & $38.6^{\mathrm{h}, \mathrm{z}}$ & $39.7^{\mathrm{e}, \mathrm{y}}$ & $42.0^{\mathrm{e}, \mathrm{x}}$ & $48.5^{\mathrm{f}, \mathrm{w}}$ & $56.9^{\text {cde }, \mathrm{v}}$ \\
\hline Rectus femoris & $39.1^{\text {def,z }}$ & $40.0^{\mathrm{de}, \mathrm{y}}$ & $44.5^{\mathrm{c}, \mathrm{x}}$ & $52.3^{\mathrm{c}, \mathrm{w}}$ & $58.3^{\mathrm{bcd}, \mathrm{v}}$ \\
\hline Vastus lateralis & $39.6^{\mathrm{c}, \mathrm{z}}$ & $40.4^{\mathrm{bcd}, \mathrm{y}}$ & $45.5^{\mathrm{b}, \mathrm{x}}$ & $57.6^{\mathrm{b}, \mathrm{w}}$ & $60.1^{\mathrm{ab}, \mathrm{v}}$ \\
\hline Semitendinosus & $41.6^{\mathrm{a}, \mathrm{z}}$ & $42.0^{\mathrm{a}, \mathrm{y}}$ & $45.8^{\mathrm{b}, \mathrm{x}}$ & $50.5^{\mathrm{de}, \mathrm{w}}$ & $56.8^{\text {cde,v }}$ \\
\hline Adductor & $40.5^{\mathrm{b}, \mathrm{z}}$ & $41.8^{\mathrm{a}, \mathrm{y}}$ & $47.0^{\mathrm{a}, \mathrm{x}}$ & $57.4^{\mathrm{b}, \mathrm{w}}$ & $61.9^{\mathrm{a}, \mathrm{v}}$ \\
\hline Infraspinatus & $39.0^{\mathrm{fg}, \mathrm{z}}$ & $40.0^{\mathrm{de}, \mathrm{y}}$ & $44.3^{\mathrm{c}, \mathrm{x}}$ & $50.4^{\mathrm{de}, \mathrm{w}}$ & $55.1^{\mathrm{ef}, \mathrm{v}}$ \\
\hline Teres major & $39.5^{\mathrm{c}, \mathrm{z}}$ & $40.4^{\mathrm{bcd}, \mathrm{y}}$ & $46.2^{\mathrm{b}, \mathrm{x}}$ & $56.1^{\mathrm{b}, \mathrm{v}}$ & $53.7^{\mathrm{f}, \mathrm{w}}$ \\
\hline Biceps femoris ischiatic head & $39.4^{\mathrm{cd}, \mathrm{z}}$ & $40.2^{\text {cde, } y}$ & $43.2^{\mathrm{d}, \mathrm{x}}$ & $50.5^{\mathrm{de}, \mathrm{w}}$ & $56.6^{\mathrm{de}, \mathrm{v}}$ \\
\hline Biceps femoris sirloin cap & $39.1^{\mathrm{ef}, \mathrm{z}}$ & $40.8^{\mathrm{b}, \mathrm{y}}$ & $47.3^{\mathrm{a}, \mathrm{x}}$ & $63.9^{\mathrm{a}, \mathrm{v}}$ & $60.0^{\mathrm{ab}, \mathrm{w}}$ \\
\hline Gracillus & $36.8^{\mathrm{i}, \mathrm{z}}$ & $38.2^{\mathrm{f}, \mathrm{y}}$ & $41.6^{\mathrm{ef}, \mathrm{x}}$ & $51.3^{\mathrm{cd}, \mathrm{w}}$ & $54.2^{\mathrm{f}, \mathrm{v}}$ \\
\hline SEM & 1.0 & & & & \\
\hline$P>\mathrm{F}$ & $<0.001$ & & & & \\
\hline
\end{tabular}

${ }^{\mathrm{a}-\mathrm{i}}$ Within a column, least squares means lacking common superscripts differ $(P<0.05)$.

${ }^{\mathrm{v}-\mathrm{Z}}$ Within a row, least squares means lacking common superscripts differ $(P<0.05)$.

LL, BFIH, and GR steaks had an increase $(P<0.05)$ in chroma values between $\mathrm{d} 0$ and 1 before declining progressively thereafter. Additionally, chroma values did not differ between d 0 and 1 in SN, IS, and TM steaks. On d 0, LL steak color was less intense $(P<0.05)$ than the color of BF, SM, AD, GM, VL, or SN steaks, but on d 9, LL steaks had greater color intensity than all other muscles included in the study except SN.

As with other color traits, muscles differed greatly in $\Delta \mathrm{E}$ from d 0 as display progressed (Table 6). By d 3 and 6 of display, large differences in color change were evident across the muscles included in this study with BFSC having the greatest color change, followed by the $\mathrm{AD}$ and VL. In contrast, LL, IS, and BFIH had undergone the least color change on d 3 and 6 of display. On d 9, the greatest color change had occurred in the
$\mathrm{BF}, \mathrm{AD}, \mathrm{VL}, \mathrm{BFSC}$, and GM, whereas the least color change had occurred in the LL and IS.

Muscle $\mathrm{pH}$ and myoglobin concentration was measured in 5 of the muscles included in this experiment (Table 7). Muscle $\mathrm{pH}$ was less $(P<0.05)$ in BF steaks than in LL or TB steaks. However, differences across mean $\mathrm{pH}$ among the 5 muscles were small. Myoglobin concentration was least $(P<0.05)$ in LL steaks and greatest $(P<0.05)$ in TB steaks. Gluteus medius steaks had greater $(P<0.05)$ myoglobin concentrations than $\mathrm{BF}$ and SM steaks.

From these results, it is clear that initial color and the timing and magnitude of color change is muscle dependent. The large differences in color and color change detected in the present experiment generally were consistent with those reported by previous investigators

Table 5. Least squares means for chroma values of steaks from 14 beef muscles placed in simulated retail display for $9 \mathrm{~d}$

\begin{tabular}{|c|c|c|c|c|c|}
\hline Muscle & Day 0 & Day 1 & Day 3 & Day 6 & Day 9 \\
\hline Semimembranosus & $44.6^{\mathrm{a}, \mathrm{z}}$ & $43.7^{\mathrm{a}, \mathrm{y}}$ & $39.2^{\mathrm{c}, \mathrm{x}}$ & $33.2^{\mathrm{c}, \mathrm{w}}$ & $28.1^{\mathrm{b}, \mathrm{v}}$ \\
\hline Gluteus medius & $44.2^{\mathrm{ab}, \mathrm{z}}$ & $41.7^{\mathrm{b}, \mathrm{y}}$ & $36.4^{\mathrm{e}, \mathrm{x}}$ & $30.1^{\mathrm{de}, \mathrm{w}}$ & $25.6^{\mathrm{cde}, \mathrm{v}}$ \\
\hline Triceps brachii & $42.3^{\text {def,z }}$ & $40.9^{b c, y}$ & $36.1^{\mathrm{e}, \mathrm{x}}$ & $29.9^{\mathrm{e}, \mathrm{w}}$ & $25.2^{\mathrm{def}, \mathrm{v}}$ \\
\hline Rectus femoris & $42.6^{\mathrm{de}, \mathrm{z}}$ & $40.5^{\mathrm{c}, \mathrm{y}}$ & $34.9^{\mathrm{fg}, \mathrm{x}}$ & $28.5^{\mathrm{fg}, \mathrm{w}}$ & $25.1^{\mathrm{ef,v}}$ \\
\hline Adductor & $44.5^{\mathrm{ab}, \mathrm{z}}$ & $41.9^{\mathrm{b}, \mathrm{y}}$ & $35.8^{\mathrm{ef}, \mathrm{x}}$ & $29.6^{\mathrm{e}, \mathrm{w}}$ & $26.1^{\mathrm{cd}, \mathrm{v}}$ \\
\hline Infraspinatus & $36.0^{\mathrm{i}, \mathrm{z}}$ & $36.7^{\mathrm{f,z}}$ & $33.8^{\mathrm{h}, \mathrm{y}}$ & $29.2^{\mathrm{ef}, \mathrm{x}}$ & $24.3^{\mathrm{fg}, \mathrm{w}}$ \\
\hline Teres major & $40.0^{\mathrm{g}, \mathrm{z}}$ & $39.4^{\mathrm{d}, \mathrm{z}}$ & $34.9^{\mathrm{fg}, \mathrm{y}}$ & $28.2^{\mathrm{g}, \mathrm{x}}$ & $26.6^{\mathrm{c,w}}$ \\
\hline Biceps femoris ischiatic head & $41.6^{\mathrm{f}, \mathrm{y}}$ & $43.5^{\mathrm{a}, \mathrm{z}}$ & $41.0^{\mathrm{a}, \mathrm{y}}$ & $33.9^{\mathrm{c}, \mathrm{x}}$ & $26.4^{\mathrm{c}, \mathrm{w}}$ \\
\hline Biceps femoris sirloin cap & $41.8^{\mathrm{eff}, \mathrm{z}}$ & $38.4^{\mathrm{e}, \mathrm{y}}$ & $31.6^{\mathrm{i}, \mathrm{x}}$ & $24.2^{\mathrm{i}, \mathrm{w}}$ & $23.3^{\mathrm{g}, \mathrm{v}}$ \\
\hline Gracillus & $37.3^{\mathrm{h}, \mathrm{y}}$ & $38.2^{\mathrm{e}, \mathrm{z}}$ & $34.6 \mathrm{~g}^{\mathrm{h}, \mathrm{x}}$ & $25.8^{\mathrm{h}, \mathrm{w}}$ & $21.6^{\mathrm{h}, \mathrm{v}}$ \\
\hline
\end{tabular}

${ }^{\mathrm{a}-\mathrm{i}}$ Within a column, least squares means lacking common superscripts differ $(P<0.05)$.

${ }^{\mathrm{v}-\mathrm{z}}$ Within a row, least squares means lacking common superscripts $\operatorname{differ}(P<0.05)$. 
Table 6. Least squares means for overall color change from d $0(\Delta \mathrm{E})$ values of steaks from 14 beef muscles placed in simulated retail display for $9 \mathrm{~d}$

\begin{tabular}{|c|c|c|c|c|}
\hline Muscle & Day 1 & Day 3 & Day 6 & Day 9 \\
\hline Longissimus lumborum & $3.1^{\mathrm{g}, \mathrm{w}}$ & $4.2^{\mathrm{h}, \mathrm{x}}$ & $8.2^{\mathrm{j}, \mathrm{y}}$ & $15.1^{\mathrm{f}, \mathrm{z}}$ \\
\hline Semimembranosus & $2.8^{\mathrm{g}, \mathrm{w}}$ & $6.6^{\mathrm{ef}, \mathrm{x}}$ & $12.6^{\mathrm{g}, \mathrm{y}}$ & $18.9^{\mathrm{d}, \mathrm{z}}$ \\
\hline Biceps femoris & $2.7^{\mathrm{g}, \mathrm{w}}$ & $7.5^{\mathrm{e}, \mathrm{x}}$ & $15.3^{\mathrm{de}, \mathrm{y}}$ & $23.0^{\mathrm{a}, \mathrm{z}}$ \\
\hline Gluteus medius & $4.2^{\mathrm{bcde}, \mathrm{w}}$ & $9.4^{\mathrm{cd}, \mathrm{x}}$ & $16.1^{\mathrm{cd}, \mathrm{y}}$ & $22.1^{\mathrm{ab}, \mathrm{z}}$ \\
\hline Triceps brachii & $3.2^{\mathrm{fg}, \mathrm{w}}$ & $7.5^{\mathrm{e}, \mathrm{x}}$ & $14.3^{\mathrm{f}, \mathrm{y}}$ & $20.6^{\mathrm{c}, \mathrm{z}}$ \\
\hline Rectus femoris & $4.4^{\text {abcde,w }}$ & $9.5^{\mathrm{cd}, \mathrm{x}}$ & $16.7^{\mathrm{c}, \mathrm{y}}$ & $21.2^{\mathrm{bc}, \mathrm{z}}$ \\
\hline Vastus lateralis & $4.7^{\mathrm{abcd}, \mathrm{w}}$ & $10.2^{\mathrm{bc}, \mathrm{x}}$ & $19.4^{\mathrm{b}, \mathrm{y}}$ & $22.7^{\mathrm{a}, \mathrm{z}}$ \\
\hline Semitendinosus & $3.4^{\mathrm{efg}, \mathrm{w}}$ & $5.6^{\mathrm{g}, \mathrm{x}}$ & $10.4^{\mathrm{i}, \mathrm{y}}$ & $16.6^{\mathrm{e}, \mathrm{z}}$ \\
\hline Adductor & $5.0^{\mathrm{abc}, \mathrm{w}}$ & $10.8^{\mathrm{b}, \mathrm{x}}$ & $18.8^{\mathrm{b}, \mathrm{y}}$ & $22.9^{\mathrm{a}, \mathrm{z}}$ \\
\hline Infraspinatus & $4.0^{\text {cdef,w }}$ & $6.3^{\mathrm{f}, \mathrm{x}}$ & $11.1^{\text {hi,y }}$ & $15.4^{\mathrm{f}, \mathrm{z}}$ \\
\hline Teres major & $5.3^{\mathrm{a}, \mathrm{w}}$ & $8.9^{\mathrm{d}, \mathrm{x}}$ & $16.1^{\mathrm{cd}, \mathrm{y}}$ & $17.1^{\mathrm{e}, \mathrm{z}}$ \\
\hline Biceps femoris ischiatic head & $3.5^{\text {efg,w }}$ & $4.6^{\mathrm{h}, \mathrm{x}}$ & $11.9^{\mathrm{gh}, \mathrm{y}}$ & $18.9^{\mathrm{d}, \mathrm{z}}$ \\
\hline Biceps femoris sirloin cap & $5.2^{\mathrm{ab}, \mathrm{x}}$ & $12.2^{\mathrm{a}, \mathrm{y}}$ & $22.5^{\mathrm{a}, \mathrm{z}}$ & $22.2^{\mathrm{a}, \mathrm{z}}$ \\
\hline Gracillus & $3.9^{\mathrm{def}, \mathrm{w}}$ & $6.7^{\mathrm{ef}, \mathrm{x}}$ & $14.5^{\text {ef,y }}$ & $18.8^{\mathrm{d}, \mathrm{z}}$ \\
\hline SEM & 0.66 & & & \\
\hline$P>\mathrm{F}$ & $<0.001$ & & & \\
\hline
\end{tabular}

${ }^{\mathrm{a}-\mathrm{j}}$ Within a column, least squares means lacking common superscripts differ $(P<0.05)$.

${ }^{\mathrm{w}-\mathrm{z}}$ Within a row, least squares means lacking common superscripts differ $(P<0.05)$.

(McKenna et al., 2005; Seyfert et al., 2006). Differences in color stability across muscles have generally been attributed to greater oxygen consumption in muscles with less stable color attributes (O'Keefe and Hood, 1982; Faustman and Cassens, 1991; Lanari and Cassens, 1991; McKenna et al., 2005) because oxygen-scavenging enzymes compete with myoglobin for oxygen resulting in greater concentrations of deoxymyoglobin, which is more susceptible to oxidation than oxymyoglobin. These differences in oxygen consumption and, consequently, color stability are generally attributed to differences in muscle fiber type distributions across muscles.

Muscle fiber type distributions are known to differ considerably across muscles that differ in location and function within the living animal (Hunt and Hedrick, 1977; Klont et al., 1998). Muscles with greater concentration of red fibers have greater concentrations of mitochondria, resulting in greater oxygen consumption and less color stability (Renerre and Labas, 1987; Klont et al., 1998; McKenna et al., 2005). Thus, the existing literature has focused on muscle differences as a primary source of variation in lean color stability and has studied those differences in an attempt to elucidate mechanisms responsible for those differences. The results of the present experiment generally support these previous findings. Myoglobin concentration can be used as an indicator of the degree of oxidative metabolism of a muscle. In the present experiment, myoglobin was determined on the 5 muscles that are commonly sold as steaks at retail. Of these, LL steaks had the least myoglobin concentrations and were also the most stable muscle evaluated in this study. Triceps brachii steaks had the greatest myoglobin content of the muscles measured, but for most of the color traits evaluated TB steaks did not differ from BF and GM steaks at the end of display. Semimembranosus and BF steaks had similar myoglobin concentration, but SM steaks had more stable lean color than BF steaks. Thus, the results of the present experiment are partially consistent with the notion that highly oxidative muscles are less color stable than less oxidative muscles. In agreement with our findings, McKenna et al. (2005) reported that muscles with greater oxygen consumption rate generally were associated with decreased color stability, although some muscles with similar oxygen consumption properties differed considerably with regard to color stability.

\section{Correlation of Muscle Color with LL Color During Display}

A primary objective of this study was to determine the extent to which animal variation observed in LL steaks is indicative of animal variation in other muscles from the carcass. Genetics and antemortem management have been demonstrated to influence fiber type distribution within a common muscle across animals (May et al., 1977; Klont et al., 1998; Vestergaard et al., 2000). Variation in homologous muscles across carcasses with regard to fiber type distribution likely results

Table 7. Least squares means for muscle $\mathrm{pH}$ and myoglobin concentration

\begin{tabular}{lcc}
\hline \hline Item & $\mathrm{pH}$ & $\begin{array}{c}\text { Myoglobin, } \\
\mathrm{mg} / \mathrm{mL}\end{array}$ \\
\hline Longissimus lumborum & $5.59^{\mathrm{z}}$ & $3.67^{\mathrm{w}}$ \\
Semimembranosus & $5.55^{\mathrm{yz}}$ & $4.35^{\mathrm{x}}$ \\
Biceps femoris & $5.53^{\mathrm{y}}$ & $4.57^{\mathrm{x}}$ \\
Gluteus medius & $5.56^{\mathrm{yz}}$ & $4.94^{\mathrm{y}}$ \\
Triceps brachii & $5.57^{\mathrm{z}}$ & $5.21^{\mathrm{z}}$ \\
SEM & 0.03 & 0.12 \\
$P>$ F & 0.03 & $<0.001$ \\
\hline
\end{tabular}

\footnotetext{
${ }^{\mathrm{w}-\mathrm{z}}$ Least squares means within a column lacking common super-
} scripts differ $(P<0.05)$. 
in variation in oxygen consumption and metmyoglobin reducing ability and, consequently, color stability. Previous work from our laboratory has indicated that substantial interanimal variation exists in oxygen consumption and metmyoglobin reducing activity, which contributes to variation in LL lean color stability (King et al., 2011). Furthermore, these differences are, to some extent, genetically regulated (King et al., 2010). Thus, opportunity exists to develop strategies to manage LM lean color stability. We were interested in determining if technology developed for such management also would affect other muscles in the carcass.

The magnitude and timing of color deterioration during display is muscle dependent, and therefore, correlation analyses examining the relationships across muscles differing in color stability on a single day of display may not adequately represent the relationship in color stability because the muscles will be at different stages of discoloration. For example, LL and BFSC were the most and least stable muscles included in the present study, respectively, but considerable variation in color stability existed in both muscles. By d 9, the LL was showing moderate color change relative to d 0 values, whereas BFSC had undergone extensive color degradation by $\mathrm{d} 6$. If the correlation between the 2 muscles was done on d 9, variation in BFSC values would be underestimated because all of the BFSC steaks would be close to complete discoloration. Thus, the more rapidly a muscle discolored, the earlier in display its greatest variation in color traits would be evident. Similarly, in a color stable muscle, later days of display would better demonstrate such variability.

Correlation coefficients between $\mathrm{L}^{*}$ values measured on LL steaks to $\mathrm{L}^{*}$ values measured on 13 other beef muscles on d $0,1,3,6$, and 9 of display are presented in Table 8 . Within the LL steaks, $\mathrm{L}^{*}$ was highly $(P$ $<0.05 ; \mathrm{r} \geq 0.84)$ correlated with $\mathrm{L}^{*}$ measured on the same steak on any other day of display. Additionally, regardless of day of display, $\mathrm{L}^{*}$ values of LL were correlated $(P<0.05)$ with $L^{*}$ values of steaks from all of the muscles included in this study. Moreover, within a muscle, correlation coefficients were remarkably consistent across days of display. Correlation coefficients were greatest when GM and SM steak $\mathrm{L}^{*}$ values were compared with LL steak $\mathrm{L}^{*}$ values and least when IS steak $\mathrm{L}^{*}$ values were compared with LL L* values.

Correlations between $a^{*}$ values of LL steaks to $a^{*}$ values of other muscles measured throughout display are presented in Table 9. It is interesting that in LL steaks, $\mathrm{a}^{*}$ values determined on $\mathrm{d} 0$ are negatively correlated with $a^{*}$ values measured on d 9 of display. In the latter portion of the display period, $\mathrm{a}^{*}$ of all of the individual muscles was positively correlated with $\mathrm{a}^{*}$ of LL on corresponding days. For most of the muscles evaluated in this study, the strongest relationship to LL a* was observed when d $6 \mathrm{a}^{*}$ values of the muscle were compared with d $9 \mathrm{LL} \mathrm{a}^{*}$ values. This is consistent with changes in a* values being less extensive through 9 $\mathrm{d}$ of display in LL than in the other muscles evaluated in this study. It is notable that the greatest relationship between $a^{*}$ values of BFSC steaks and LL steaks was detected when d 3 BFSC a* values were compared with d $9 \mathrm{LL} \mathrm{a}^{*}$ values. This is consistent with BFSC having the greatest decreases in $\mathrm{a}^{*}$ between $\mathrm{d} 3$ and 6 after which $a^{*}$ values did not change. In contrast, SM, $\mathrm{SN}$, and GM a* values were most correlated with LL $\mathrm{a}^{*}$ values when both were measured on d 9 of display. The SN and SM had a* values most similar to LL on d 6 and 9 of display.

It is interesting that in LL steaks, $a^{*}$ values determined on d 0 are negatively correlated with $a^{*}$ values measured on d 9 of display. This is consistent with previous results from our laboratory in which LL steaks classified as having labile lean color had greater a* values at the beginning of display compared with those classified as having stable lean color (King et al., 2011). In that study, steaks classified as having labile lean color had greater decreases in a* value during display and had smaller a* values at the end of display than those classified as stable.

Longissimus lumborum $\mathrm{b}^{*}$ values measured on $\mathrm{d} 0$ or 1 were generally positively correlated $(P<0.05)$ with $b^{*}$ values of other muscles measured on $\mathrm{d} 0,1$, or 9 , but were generally either not correlated or negatively correlated with those measured on d 3 or 6 (Table 10). Day $6 \mathrm{LL} \mathrm{b}^{*}$ values were positively correlated with the $\mathrm{d} 6$ values for SM, BF, GM, AD, SN, IS, TM, and BFIH. Day 9 LL b* values were positively correlated with d 6 values for SM, TB, RF, VL, AD, SN, IS, TM, BFIH, and BFSC.

Relationships among chroma values of LL steaks during display and those of other muscles included in the study were very similar to those detected for $a^{*}$ values (Table 11). Day 0 LL chroma values were positively correlated with d 0 chroma values of the other muscles included in this study, but negatively correlated with the chroma values of those muscles measured later in the display period. Furthermore, chroma values determined on LL steaks late in the display period were positively correlated with those measured on the other muscles late in the display period. In some less stable muscles (RF, VL, AD, IS, BFSC, and GR), color intensity on d 9 of display was negatively correlated with LL color intensity on d 6 or 9 of display.

Hue angle of all muscles was moderately to highly correlated $(P<0.05)$ with hue angle of LL throughout display (Table 12). Within a muscle, the greatest correlation coefficients to LL hue angle occurred when both muscles were measured on d 0 or 1 . At the end of display, the greatest correlations were generally observed when the hue angle of the muscle measured on $\mathrm{d} 6$ was compared with LL hue angle measured on d 9.

As noted previously, overall color change in LL was less extensive throughout display than the other muscles. However, when measured on d 6 and $9, \Delta \mathrm{E}$ values of each of the muscles was moderately to highly correlated $(P<0.05)$ with $\Delta \mathrm{E}$ in the LL on d 6 and 9 (Table $13)$. When the correlation coefficients between the color 
Table 8. Pearson correlation coefficients between lightness $\left(\mathrm{L}^{*}\right)$ values of longissimus lumborum steaks and steaks from 13 beef muscles measured on d $0,1,3,6$, and 9 of display

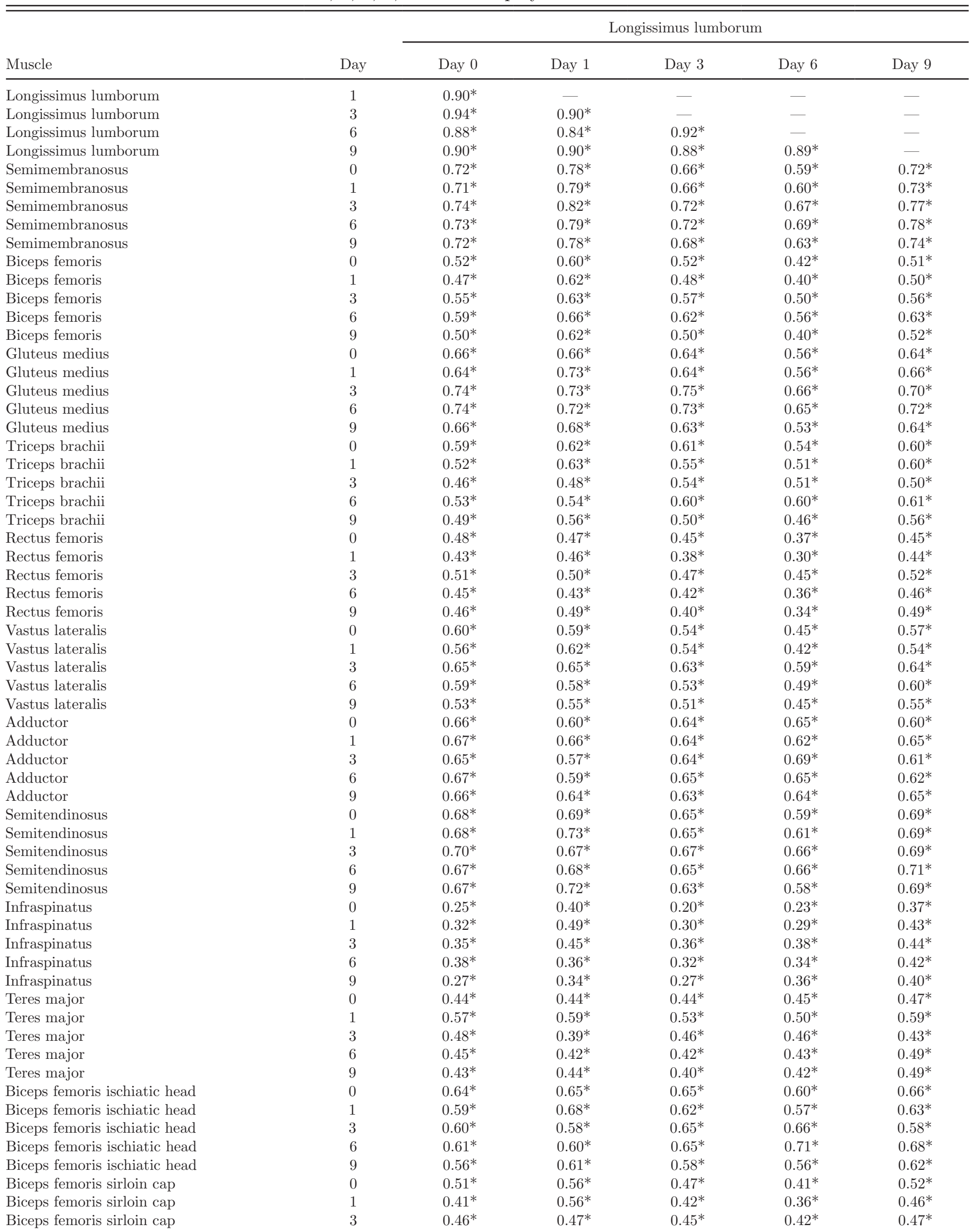


Table 8 (Continued). Pearson correlation coefficients between lightness $\left(\mathrm{L}^{*}\right)$ values of longissimus lumborum steaks and steaks from 13 beef muscles measured on d $0,1,3,6$, and 9 of display

\begin{tabular}{|c|c|c|c|c|c|c|}
\hline \multirow[b]{2}{*}{ Muscle } & \multirow[b]{2}{*}{ Day } & \multicolumn{5}{|c|}{ Longissimus lumborum } \\
\hline & & Day 0 & Day 1 & Day 3 & Day 6 & Day 9 \\
\hline Biceps femoris sirloin cap & 9 & $0.48^{*}$ & $0.59^{*}$ & $0.47^{*}$ & $0.53^{*}$ & $0.60^{*}$ \\
\hline Gracillus & 0 & $0.53^{*}$ & $0.55^{*}$ & $0.48^{*}$ & $0.36^{*}$ & $0.45^{*}$ \\
\hline Gracillus & 1 & $0.46^{*}$ & $0.59^{*}$ & $0.43^{*}$ & $0.30 *$ & $0.42^{*}$ \\
\hline Gracillus & 9 & $0.52^{*}$ & $0.58^{*}$ & $0.48^{*}$ & $0.42^{*}$ & $0.53^{*}$ \\
\hline
\end{tabular}

$* P<0.05$.

Table 9. Pearson correlation coefficients between redness $\left(a^{*}\right)$ values of longissimus lumborum steaks and steaks from 13 beef muscles measured on d $0,1,3,6$, and 9 of display

\begin{tabular}{|c|c|c|c|c|c|c|}
\hline Muscle & Day & Day 0 & Day 1 & Day 3 & Day 6 & Day 9 \\
\hline Longissimus lumborum & 3 & $0.29^{*}$ & $0.54^{*}$ & - & - & - \\
\hline Longissimus lumborum & 6 & -0.14 & 0.18 & $0.39^{*}$ & - & - \\
\hline Longissimus lumborum & 9 & $-0.20^{*}$ & 0.05 & $0.23^{*}$ & $0.65^{*}$ & - \\
\hline Semimembranosus & 3 & $-0.31^{*}$ & -0.07 & 0.31 & $0.35^{*}$ & $0.44^{*}$ \\
\hline Semimembranosus & 6 & $-0.39^{*}$ & -0.17 & 0.20 & $0.50 *$ & $0.59^{*}$ \\
\hline Semimembranosus & 9 & $-0.43^{*}$ & $-0.21^{*}$ & 0.00 & $0.50^{*}$ & $0.61^{*}$ \\
\hline Biceps femoris & 0 & $0.28^{*}$ & $0.24^{*}$ & $0.20^{*}$ & $-0.20^{*}$ & $-0.25^{*}$ \\
\hline Biceps femoris & 1 & -0.09 & 0.10 & $0.26^{*}$ & $0.23^{*}$ & 0.19 \\
\hline Biceps femoris & 3 & $-0.33^{*}$ & $-0.28^{*}$ & $0.23^{*}$ & $0.37^{*}$ & $0.46^{*}$ \\
\hline Gluteus medius & 6 & $-0.39^{*}$ & $-0.29^{*}$ & 0.17 & $0.50 *$ & $0.51^{*}$ \\
\hline Gluteus medius & 9 & $-0.32^{*}$ & $-0.20^{*}$ & -0.04 & $0.40^{*}$ & $0.52^{*}$ \\
\hline Triceps brachii & 0 & $0.23^{*}$ & $0.20^{*}$ & 0.08 & -0.06 & -0.05 \\
\hline Triceps brachii & 1 & 0.01 & $0.25^{*}$ & $0.27^{*}$ & $0.43^{*}$ & $0.40^{*}$ \\
\hline Triceps brachii & 3 & $-0.20^{*}$ & -0.10 & $0.29^{*}$ & $0.27^{*}$ & $0.39^{*}$ \\
\hline Triceps brachii & 6 & $-0.22^{*}$ & 0.01 & $0.27^{*}$ & $0.71^{*}$ & $0.72^{*}$ \\
\hline Triceps brachii & 9 & -0.16 & -0.01 & 0.13 & 0.30 & 0.65 \\
\hline Rectus femoris & 0 & $0.26^{*}$ & $0.20^{*}$ & 0.04 & -0.03 & -0.02 \\
\hline Rectus femoris & 1 & -0.08 & 0.18 & 0.17 & $0.52 *$ & $0.50^{*}$ \\
\hline Rectus femoris & 3 & $-0.22^{*}$ & -0.10 & 0.17 & $0.37^{*}$ & $0.52^{*}$ \\
\hline Rectus femoris & 6 & -0.15 & 0.00 & $0.23^{*}$ & $0.52^{*}$ & $0.60^{*}$ \\
\hline Rectus femoris & 9 & -0.12 & -0.06 & -0.02 & 0.19 & $0.45^{*}$ \\
\hline Adductor & 6 & $-0.36^{*}$ & -0.18 & 0.09 & $0.60^{*}$ & $0.65^{*}$ \\
\hline Adductor & 9 & $-0.29^{*}$ & -0.14 & -0.06 & $0.27^{*}$ & $0.57^{*}$ \\
\hline Semitendinosus & 0 & $0.45^{*}$ & $0.49^{*}$ & 0.15 & 0.07 & 0.06 \\
\hline Semitendinosus & 1 & -0.05 & $0.28^{*}$ & 0.07 & $0.30^{*}$ & 0.20 \\
\hline Semitendinosus & 3 & $-0.27^{*}$ & -0.11 & 0.15 & $0.28^{*}$ & $0.32^{*}$ \\
\hline Semitendinosus & 6 & $-0.31^{*}$ & -0.03 & 0.11 & $0.62^{*}$ & $0.65^{*}$ \\
\hline Semitendinosus & 9 & -0.19 & 0.01 & 0.11 & $0.56^{*}$ & $0.80^{*}$ \\
\hline
\end{tabular}


Table 9 (Continued). Pearson correlation coefficients between redness $\left(a^{*}\right)$ values of longissimus lumborum steaks and steaks from 13 beef muscles measured on d $0,1,3,6$, and 9 of display

\begin{tabular}{|c|c|c|c|c|c|c|}
\hline Muscle & Day & Day 0 & Day 1 & Day 3 & Day 6 & Day 9 \\
\hline Infraspinatus & 1 & 0.12 & $0.37^{*}$ & $0.20^{*}$ & $0.30^{*}$ & $0.52^{*}$ \\
\hline Infraspinatus & 3 & -0.09 & 0.09 & $0.21^{*}$ & $0.30^{*}$ & $0.44^{*}$ \\
\hline Infraspinatus & 6 & -0.12 & 0.06 & $0.27^{*}$ & $0.50^{*}$ & $0.59^{*}$ \\
\hline Teres major & 1 & -0.17 & 0.10 & $0.34^{*}$ & $0.37^{*}$ & 0.35 \\
\hline Teres major & 3 & $-0.32^{*}$ & -0.18 & $0.31^{*}$ & $0.21^{*}$ & $0.33^{*}$ \\
\hline Teres major & 6 & -0.18 & -0.02 & $0.25^{*}$ & $0.25^{*}$ & $0.50^{*}$ \\
\hline Teres major & 9 & -0.16 & -0.13 & -0.10 & $-0.32^{*}$ & $-0.22^{*}$ \\
\hline Biceps femoris ischiatic head & 0 & $0.48^{*}$ & $0.45^{*}$ & 0.11 & -0.03 & -0.04 \\
\hline Biceps femoris ischiatic head & 1 & $0.27^{*}$ & $0.47^{*}$ & $0.21^{*}$ & $0.39^{*}$ & $0.25^{*}$ \\
\hline Biceps femoris sirloin cap & 3 & $-0.28^{*}$ & -0.18 & 0.14 & $0.47^{*}$ & $0.67^{*}$ \\
\hline Biceps femoris sirloin cap & 6 & $-0.26^{*}$ & -0.18 & -0.10 & $0.28^{*}$ & $0.55^{*}$ \\
\hline Biceps femoris sirloin cap & 9 & $-0.17^{*}$ & $-0.22^{*}$ & $-0.23^{*}$ & $-0.44^{*}$ & $-0.31^{*}$ \\
\hline Gracillus & 0 & $0.31^{*}$ & $0.27^{*}$ & -0.03 & 0.15 & 0.15 \\
\hline Gracillus & 1 & 0.11 & $0.26^{*}$ & 0.12 & $0.50^{*}$ & $0.49^{*}$ \\
\hline Gracillus & 3 & -0.01 & -0.08 & 0.18 & $0.34^{*}$ & $0.51^{*}$ \\
\hline Gracillus & 6 & $-0.26^{*}$ & -0.17 & 0.05 & $0.48^{*}$ & $0.68^{*}$ \\
\hline Gracillus & 9 & $-0.22^{*}$ & -0.18 & -0.16 & -0.10 & 0.12 \\
\hline
\end{tabular}

$* P<0.05$.

Table 10. Pearson correlation coefficients between yellowness ( $\left.b^{*}\right)$ values of longissimus lumborum steaks and steaks from 13 beef muscles measured on d $0,1,3,6$, and 9 of display

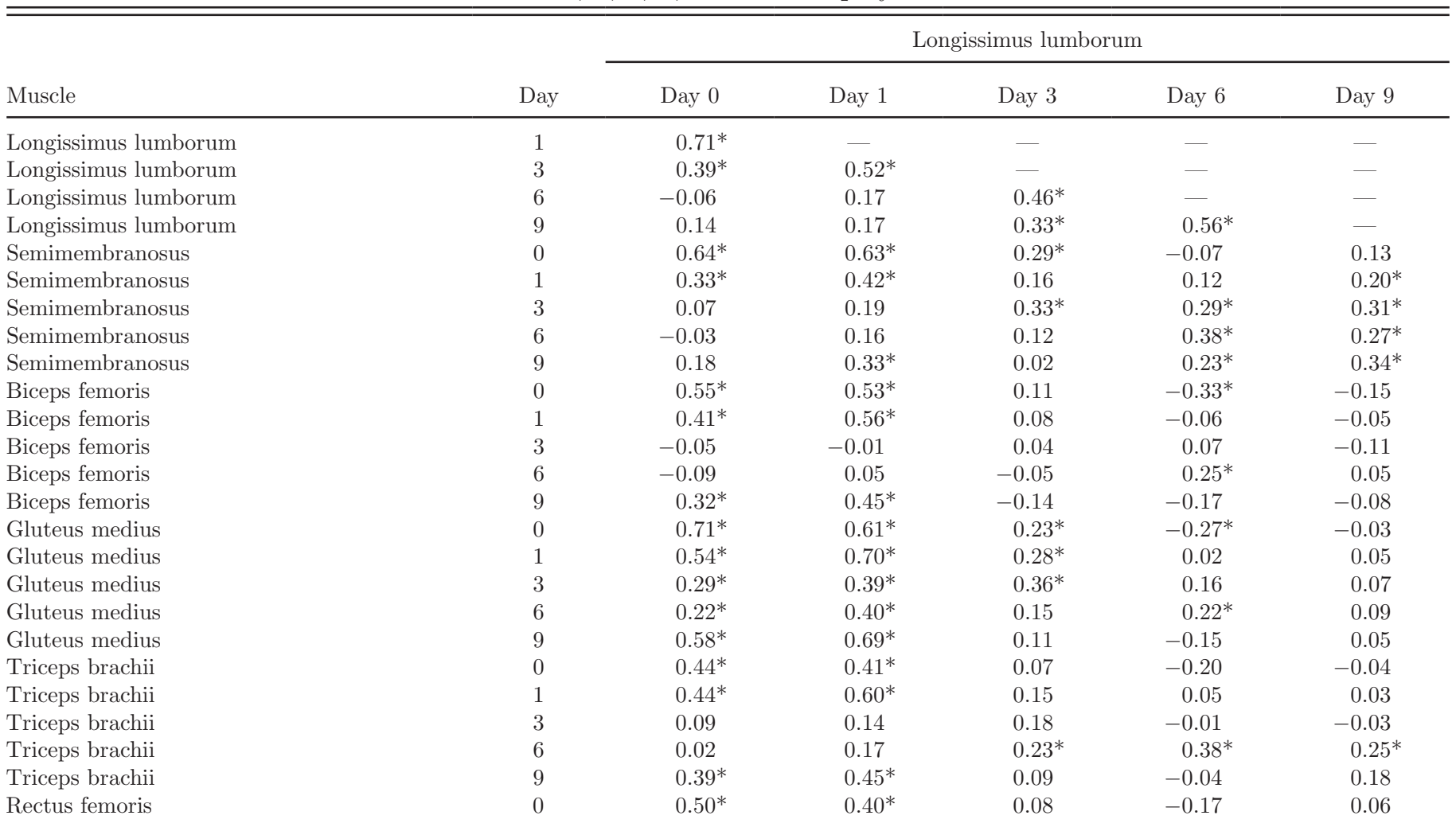


Table 10 (Continued). Pearson correlation coefficients between yellowness $\left(b^{*}\right)$ values of longissimus lumborum steaks and steaks from 13 beef muscles measured on d $0,1,3,6$, and 9 of display

\begin{tabular}{|c|c|c|c|c|c|c|}
\hline Muscle & Day & Day 0 & Day 1 & Day 3 & Day 6 & Day 9 \\
\hline Rectus femoris & 3 & -0.19 & $-0.25^{*}$ & -0.07 & 0.03 & 0.11 \\
\hline Rectus femoris & 6 & -0.14 & -0.02 & 0.03 & 0.27 & $0.25^{*}$ \\
\hline Rectus femoris & 9 & $0.37^{*}$ & $0.33^{*}$ & -0.13 & -0.30 & 0.04 \\
\hline Vastis lateralis & 3 & -0.17 & $-0.23^{*}$ & -0.07 & 0.15 & $0.24^{*}$ \\
\hline Vastis lateralis & 6 & 0.01 & 0.07 & -0.02 & 0.11 & $0.24^{*}$ \\
\hline Vastis lateralis & 9 & $0.33^{*}$ & 0.36 & -0.12 & $-0.25^{*}$ & 0.05 \\
\hline Adductor & 0 & $0.58^{*}$ & $0.52^{*}$ & 0.18 & -0.19 & 0.08 \\
\hline Adductor & 1 & $0.48^{*}$ & $0.61^{*}$ & 0.09 & -0.09 & -0.03 \\
\hline Adductor & 3 & -0.03 & -0.09 & 0.16 & 0.16 & $0.23^{*}$ \\
\hline Semitendinosus & 6 & 0.02 & 0.24 & 0.17 & $0.42^{*}$ & $0.40^{*}$ \\
\hline Semitendinosus & 9 & $0.40^{*}$ & $0.50^{*}$ & 0.15 & 0.12 & $0.28^{*}$ \\
\hline Infraspinatus & 0 & $0.45^{*}$ & $0.29^{*}$ & 0.01 & -0.24 & -0.04 \\
\hline Infraspinatus & 1 & $0.48^{*}$ & $0.61^{*}$ & 0.18 & -0.13 & 0.00 \\
\hline Infraspinatus & 3 & -0.03 & -0.09 & $0.22^{*}$ & 0.06 & 0.02 \\
\hline Infraspinatus & 6 & -0.03 & 0.15 & $0.23^{*}$ & $0.25^{*}$ & $0.27^{*}$ \\
\hline Infraspinatus & 9 & $0.35^{*}$ & $0.42^{*}$ & -0.11 & $-0.26^{*}$ & -0.08 \\
\hline Teres major & 0 & $0.53^{*}$ & $0.39^{*}$ & 0.12 & 0.02 & $0.26^{*}$ \\
\hline Teres major & 1 & $0.35^{*}$ & $0.46^{*}$ & 0.14 & 0.01 & -0.11 \\
\hline Teres major & 3 & -0.18 & $-0.22^{*}$ & 0.13 & 0.00 & -0.04 \\
\hline Teres major & 6 & 0.10 & 0.09 & 0.25 & $0.30^{*}$ & $0.29^{*}$ \\
\hline Teres major & 9 & $0.47^{*}$ & $0.49^{*}$ & 0.09 & 0.16 & $0.22^{*}$ \\
\hline Biceps femoris sirloin cap & 6 & 0.23 & $0.25^{*}$ & 0.14 & 0.06 & $0.22^{*}$ \\
\hline Biceps femoris sirloin cap & 9 & $0.43^{*}$ & $0.44^{*}$ & -0.06 & -0.16 & -0.09 \\
\hline Gracillus & 0 & $0.45^{*}$ & $0.31^{*}$ & 0.02 & -0.09 & 0.13 \\
\hline Gracillus & 1 & $0.39^{*}$ & $0.44^{*}$ & 0.14 & 0.09 & 0.15 \\
\hline Gracillus & 3 & -0.18 & $-0.24^{*}$ & 0.13 & 0.16 & $0.20 *$ \\
\hline Gracillus & 6 & $-0.25^{*}$ & $-0.23^{*}$ & -0.11 & 0.18 & 0.18 \\
\hline Gracillus & 9 & $0.46^{*}$ & $0.45^{*}$ & -0.02 & $-0.26^{*}$ & -0.09 \\
\hline
\end{tabular}

$* P<0.05$.

Table 11. Pearson correlation coefficients between chroma values of longissimus lumborum steaks and steaks from 13 beef muscles measured on d $0,1,3,6$, and 9 of display

\begin{tabular}{|c|c|c|c|c|c|c|}
\hline \multirow[b]{2}{*}{ Muscle } & \multirow[b]{2}{*}{ Day } & \multicolumn{5}{|c|}{ Longissimus lumborum } \\
\hline & & Day 0 & Day 1 & Day 3 & Day 6 & Day 9 \\
\hline Longissimus lumborum & 1 & $0.69^{*}$ & - & - & - & - \\
\hline Longissimus lumborum & 3 & $0.35^{*}$ & $0.58^{*}$ & - & - & - \\
\hline Longissimus lumborum & 6 & -0.17 & 0.10 & $0.39^{*}$ & - & - \\
\hline Longissimus lumborum & 9 & -0.26 & -0.15 & $0.19^{*}$ & $0.63^{*}$ & - \\
\hline Semimembranosus & 0 & $0.56^{*}$ & $0.58^{*}$ & $0.22 *$ & -0.15 & $-0.28^{*}$ \\
\hline Semimembranosus & 1 & 0.16 & $0.30^{*}$ & 0.17 & 0.11 & -0.01 \\
\hline Semimembranosus & 3 & -0.18 & -0.01 & $0.29 *$ & $0.31^{*}$ & $0.33^{*}$ \\
\hline
\end{tabular}


Table 11 (Continued). Pearson correlation coefficients between chroma values of longissimus lumborum steaks and steaks from 13 beef muscles measured on d $0,1,3,6$, and 9 of display

\begin{tabular}{|c|c|c|c|c|c|c|}
\hline \multirow[b]{2}{*}{ Muscle } & \multirow[b]{2}{*}{ Day } & \multicolumn{5}{|c|}{ Longissimus lumborum } \\
\hline & & Day 0 & Day 1 & Day 3 & Day 6 & Day 9 \\
\hline Semimembranosus & 9 & $-0.36^{*}$ & -0.16 & -0.08 & $0.42^{*}$ & $0.44^{*}$ \\
\hline Biceps femoris & 0 & $0.37^{*}$ & $0.34^{*}$ & 0.13 & $-0.35^{*}$ & $-0.45^{*}$ \\
\hline Biceps femoris & 1 & 0.11 & $0.24 *$ & 0.14 & 0.03 & -0.15 \\
\hline Biceps femoris & 3 & $-0.28^{*}$ & $-0.27^{*}$ & 0.12 & $0.26^{*}$ & $0.24^{*}$ \\
\hline Biceps femoris & 9 & $-0.23^{*}$ & -0.17 & -0.25 & 0.07 & 0.02 \\
\hline Gluteus medius & 0 & $0.63^{*}$ & $0.56^{*}$ & $0.22^{*}$ & $-0.33^{*}$ & $-0.37^{*}$ \\
\hline Gluteus medius & 1 & $0.32^{*}$ & $0.43^{*}$ & $0.31^{*}$ & 0.00 & -0.19 \\
\hline Gluteus medius & 3 & -0.06 & 0.01 & 0.33 & 0.22 & 0.15 \\
\hline Gluteus medius & 6 & $-0.26^{*}$ & -0.16 & 0.10 & $0.39^{*}$ & $0.28^{*}$ \\
\hline Gluteus medius & 9 & 0.00 & 0.11 & -0.08 & 0.02 & -0.04 \\
\hline Triceps brachii & 0 & $0.25^{*}$ & $0.25^{*}$ & 0.05 & $-0.19^{*}$ & $-0.25^{*}$ \\
\hline Rectus femoris & 0 & $0.32 *$ & $0.26^{*}$ & 0.03 & -0.16 & -0.18 \\
\hline Rectus femoris & 1 & 0.01 & 0.14 & 0.06 & $0.22^{*}$ & 0.05 \\
\hline Rectus femoris & 3 & $-0.29^{*}$ & $-0.25^{*}$ & 0.02 & $0.27^{*}$ & $0.40^{*}$ \\
\hline Rectus femoris & 6 & $-0.26^{*}$ & -0.16 & 0.10 & $0.45^{*}$ & $0.47^{*}$ \\
\hline Rectus femoris & 9 & -0.08 & -0.18 & $-0.25^{*}$ & $-0.21^{*}$ & 0.02 \\
\hline Vastis lateralis & 0 & $0.25^{*}$ & $0.23^{*}$ & -0.06 & $-0.29^{*}$ & $-0.28^{*}$ \\
\hline Vastis lateralis & 1 & -0.07 & 0.00 & 0.08 & $0.25^{*}$ & 0.13 \\
\hline Vastis lateralis & 3 & $-0.30^{*}$ & $-0.29^{*}$ & 0.07 & $0.35^{*}$ & $0.49^{*}$ \\
\hline Vastis lateralis & 6 & $-0.29^{*}$ & $-0.26^{*}$ & -0.04 & $0.40^{*}$ & $0.57^{*}$ \\
\hline Vastis lateralis & 9 & 0.00 & 0.01 & -0.17 & $-0.27^{*}$ & -0.10 \\
\hline Adductor & 0 & $0.46^{*}$ & $0.45^{*}$ & 0.14 & $-0.20^{*}$ & $-0.26^{*}$ \\
\hline Adductor & 1 & 0.14 & 0.20 & 0.07 & -0.05 & $-0.33^{*}$ \\
\hline Infraspinatus & 0 & $0.22^{*}$ & 0.16 & 0.04 & -0.13 & 0.03 \\
\hline Infraspinatus & 1 & $0.22 *$ & $0.29 *$ & $0.21^{*}$ & -0.04 & 0.03 \\
\hline Infraspinatus & 3 & -0.11 & -0.05 & 0.18 & 0.18 & $0.29^{*}$ \\
\hline Infraspinatus & 6 & -0.18 & -0.04 & $0.21^{*}$ & $0.40^{*}$ & $0.48^{*}$ \\
\hline Infraspinatus & 9 & -0.04 & -0.04 & -0.14 & $-0.35^{*}$ & $-0.27^{*}$ \\
\hline Teres major & 0 & $0.43^{*}$ & $0.36^{*}$ & 0.13 & 0.01 & 0.06 \\
\hline Teres major & 1 & -0.07 & 0.07 & 0.25 & 0.16 & -0.07 \\
\hline Teres major & 3 & $-0.32^{*}$ & $-0.28^{*}$ & $0.21^{*}$ & 0.13 & $0.23^{*}$ \\
\hline Teres major & 6 & -0.16 & -0.08 & 0.25 & $0.29^{*}$ & $0.52^{*}$ \\
\hline Teres major & 9 & $0.23^{*}$ & $0.21^{*}$ & -0.04 & $-0.30^{*}$ & $-0.32^{*}$ \\
\hline Biceps femoris ischiatic head & 0 & $0.47^{*}$ & $0.42^{*}$ & 0.08 & -0.18 & $-0.24^{*}$ \\
\hline Biceps femoris ischiatic head & 1 & $0.36^{*}$ & $0.48^{*}$ & 0.14 & 0.04 & $-0.22^{*}$ \\
\hline Biceps femoris ischiatic head & 3 & 0.08 & $0.11^{*}$ & $0.27^{*}$ & $0.30^{*}$ & $0.23^{*}$ \\
\hline Biceps femoris ischiatic head & 6 & $-0.31^{*}$ & -0.15 & 0.12 & $0.68^{*}$ & $0.69^{*}$ \\
\hline Biceps femoris ischiatic head & 9 & -0.18 & -0.08 & -0.08 & 0.01 & $0.30^{*}$ \\
\hline Biceps femoris sirloin cap & 0 & $0.34^{*}$ & 0.15 & -0.03 & $-0.37^{*}$ & $-0.32^{*}$ \\
\hline Biceps femoris sirloin cap & 1 & -0.09 & -0.12 & 0.00 & 0.17 & $0.20^{*}$ \\
\hline Biceps femoris sirloin cap & 3 & $-0.30^{*}$ & $-0.32^{*}$ & 0.06 & $0.33^{*}$ & $0.51^{*}$ \\
\hline Biceps femoris sirloin cap & 6 & -0.17 & $-0.21^{*}$ & -0.11 & 0.12 & $0.33^{*}$ \\
\hline Biceps femoris sirloin cap & 9 & 0.10 & -0.02 & -0.22 & -0.48 & $-0.56^{*}$ \\
\hline Gracillus & 0 & $0.30^{*}$ & $0.21^{*}$ & -0.03 & 0.02 & 0.02 \\
\hline Gracillus & 1 & 0.10 & 0.10 & 0.11 & $0.32^{*}$ & $0.22^{*}$ \\
\hline Gracillus & 3 & -0.12 & -0.19 & 0.14 & $0.27^{*}$ & $0.45^{*}$ \\
\hline Gracillus & 6 & $-0.38^{*}$ & $-0.35^{*}$ & -0.08 & $0.37^{*}$ & $0.55^{*}$ \\
\hline Gracillus & 9 & -0.02 & -0.09 & $-0.24^{*}$ & $-0.40^{*}$ & $-0.32^{*}$ \\
\hline
\end{tabular}

$* P<0.05$. 
Table 12. Pearson correlation coefficients between hue angle values of longissimus lumborum steaks and steaks from 13 beef muscles measured on d $0,1,3,6$, and 9 of display

\begin{tabular}{|c|c|c|c|c|c|c|}
\hline \multirow[b]{2}{*}{ Muscle } & \multirow[b]{2}{*}{ Day } & \multicolumn{5}{|c|}{ Longissimus lumborum } \\
\hline & & Day 0 & Day 1 & Day 3 & Day 6 & Day 9 \\
\hline Longissimus lumborum & 1 & $0.72^{*}$ & - & - & - & - \\
\hline Longissimus lumborum & 3 & $0.38^{*}$ & $0.35^{*}$ & - & - & - \\
\hline Longissimus lumborum & 6 & $0.47^{*}$ & $0.47^{*}$ & $0.56^{*}$ & - & - \\
\hline Longissimus lumborum & 9 & $0.71^{*}$ & $0.67^{*}$ & $0.56^{*}$ & $0.62^{*}$ & - \\
\hline Semimembranosus & 0 & $0.73^{*}$ & $0.68^{*}$ & $0.46^{*}$ & $0.43^{*}$ & $0.73^{*}$ \\
\hline Semimembranosus & 1 & $0.50^{*}$ & $0.57^{*}$ & $0.37^{*}$ & 0.19 & $0.56^{*}$ \\
\hline Semimembranosus & 3 & $0.32^{*}$ & $0.38^{*}$ & $0.65^{*}$ & $0.37^{*}$ & $0.61^{*}$ \\
\hline Semimembranosus & 6 & $0.40^{*}$ & $0.41^{*}$ & $0.50^{*}$ & $0.46^{*}$ & $0.72 *$ \\
\hline Semimembranosus & 9 & $0.47^{*}$ & $0.37^{*}$ & $0.49^{*}$ & $0.53^{*}$ & $0.74 *$ \\
\hline Biceps femoris & 0 & $0.87^{*}$ & $0.75^{*}$ & $0.30^{*}$ & $0.45^{*}$ & $0.70^{*}$ \\
\hline Biceps femoris & 1 & $0.71^{*}$ & $0.86^{*}$ & $0.28^{*}$ & $0.39^{*}$ & $0.70^{*}$ \\
\hline Biceps femoris & 3 & $0.44^{*}$ & $0.39^{*}$ & $0.54^{*}$ & $0.44^{*}$ & $0.67^{*}$ \\
\hline Biceps femoris & 6 & $0.41^{*}$ & $0.40^{*}$ & $0.47^{*}$ & $0.53^{*}$ & $0.75^{*}$ \\
\hline Biceps femoris & 9 & $0.49^{*}$ & $0.47^{*}$ & $0.45^{*}$ & $0.44^{*}$ & $0.67^{*}$ \\
\hline Gluteus medius & 0 & $0.85^{*}$ & $0.64^{*}$ & $0.34^{*}$ & $0.49^{*}$ & $0.69^{*}$ \\
\hline Gluteus medius & 1 & $0.65^{*}$ & $0.89^{*}$ & $0.40^{*}$ & $0.56^{*}$ & $0.71^{*}$ \\
\hline Gluteus medius & 3 & $0.35^{*}$ & $0.32^{*}$ & $0.61^{*}$ & $0.44^{*}$ & $0.60^{*}$ \\
\hline Gluteus medius & 6 & $0.35^{*}$ & $0.32^{*}$ & $0.51^{*}$ & $0.55^{*}$ & $0.69 *$ \\
\hline Gluteus medius & 9 & $0.56^{*}$ & $0.44^{*}$ & $0.39^{*}$ & $0.50^{*}$ & $0.72 *$ \\
\hline Triceps brachii & 0 & $0.87^{*}$ & $0.63^{*}$ & $0.26^{*}$ & $0.41^{*}$ & $0.62^{*}$ \\
\hline Triceps brachii & 1 & $0.72^{*}$ & $0.92^{*}$ & $0.27^{*}$ & $0.44^{*}$ & $0.66^{*}$ \\
\hline Triceps brachii & 3 & $0.57^{*}$ & $0.49^{*}$ & $0.52^{*}$ & $0.50^{*}$ & $0.66^{*}$ \\
\hline Triceps brachii & 6 & $0.57^{*}$ & $0.52^{*}$ & $0.49^{*}$ & $0.69^{*}$ & $0.74 *$ \\
\hline Triceps brachii & 9 & $0.71^{*}$ & $0.65^{*}$ & $0.28^{*}$ & $0.35^{*}$ & $0.68^{*}$ \\
\hline Rectus femoris & 0 & $0.87^{*}$ & $0.59^{*}$ & $0.31^{*}$ & $0.38^{*}$ & $0.62^{*}$ \\
\hline Rectus femoris & 1 & $0.84^{*}$ & $0.84^{*}$ & $0.32^{*}$ & $0.48^{*}$ & $0.73^{*}$ \\
\hline Rectus femoris & 3 & $0.44^{*}$ & $0.27^{*}$ & $0.57^{*}$ & $0.39^{*}$ & $0.56^{*}$ \\
\hline Rectus femoris & 6 & $0.53^{*}$ & $0.43^{*}$ & $0.57^{*}$ & $0.50^{*}$ & $0.66^{*}$ \\
\hline Rectus femoris & 9 & $0.65^{*}$ & $0.60^{*}$ & $0.30^{*}$ & $0.33^{*}$ & $0.55^{*}$ \\
\hline Vastus lateralis & 0 & $0.85^{*}$ & $0.65^{*}$ & $0.28^{*}$ & $0.42^{*}$ & $0.69^{*}$ \\
\hline Vastus lateralis & 1 & $0.76^{*}$ & $0.85^{*}$ & $0.37^{*}$ & $0.52^{*}$ & $0.76^{*}$ \\
\hline Vastus lateralis & 3 & $0.39^{*}$ & $0.29^{*}$ & $0.54^{*}$ & $0.41^{*}$ & $0.56^{*}$ \\
\hline Vastus lateralis & 6 & $0.60^{*}$ & $0.50^{*}$ & $0.52^{*}$ & $0.54^{*}$ & $0.75^{*}$ \\
\hline Vastus lateralis & 9 & $0.37^{*}$ & $0.46^{*}$ & 0.15 & 0.14 & $0.29 *$ \\
\hline Adductor & 0 & $0.86^{*}$ & $0.64^{*}$ & $0.36^{*}$ & $0.42^{*}$ & $0.70^{*}$ \\
\hline Adductor & 1 & $0.73^{*}$ & $0.90^{*}$ & $0.37^{*}$ & $0.54^{*}$ & $0.75^{*}$ \\
\hline Adductor & 3 & 0.04 & -0.05 & $0.57^{*}$ & $0.31^{*}$ & $0.36^{*}$ \\
\hline Adductor & 6 & $0.42^{*}$ & $0.32^{*}$ & $0.54^{*}$ & $0.58^{*}$ & $0.69 *$ \\
\hline Adductor & 9 & $0.69^{*}$ & $0.64^{*}$ & $0.34^{*}$ & $0.43^{*}$ & $0.70^{*}$ \\
\hline Semitendinosus & 0 & $0.84^{*}$ & $0.65^{*}$ & $0.28^{*}$ & $0.39^{*}$ & $0.69^{*}$ \\
\hline Semitendinosus & 1 & $0.70^{*}$ & $0.89^{*}$ & $0.33^{*}$ & $0.57^{*}$ & $0.73^{*}$ \\
\hline Semitendinosus & 3 & $0.38^{*}$ & $0.28^{*}$ & $0.47^{*}$ & $0.39^{*}$ & $0.54 *$ \\
\hline Semitendinosus & 6 & $0.48^{*}$ & $0.46^{*}$ & $0.55^{*}$ & $0.61^{*}$ & $0.73^{*}$ \\
\hline Semitendinosus & 9 & $0.73^{*}$ & $0.62^{*}$ & $0.36^{*}$ & $0.57^{*}$ & $0.82 *$ \\
\hline Infraspinatus & 0 & $0.88^{*}$ & $0.64^{*}$ & $0.23^{*}$ & $0.38^{*}$ & $0.64 *$ \\
\hline Infraspinatus & 1 & $0.73^{*}$ & $0.91^{*}$ & $0.30^{*}$ & $0.51^{*}$ & $0.68^{*}$ \\
\hline Infraspinatus & 3 & $0.39^{*}$ & $0.31^{*}$ & $0.56^{*}$ & $0.48^{*}$ & $0.48^{*}$ \\
\hline Infraspinatus & 6 & $0.55^{*}$ & $0.45^{*}$ & $0.58^{*}$ & $0.57^{*}$ & $0.65^{*}$ \\
\hline Infraspinatus & 9 & $0.52^{*}$ & $0.46^{*}$ & 0.04 & 0.06 & $0.29 *$ \\
\hline Teres major & 0 & $0.79^{*}$ & $0.53^{*}$ & $0.25^{*}$ & $0.31^{*}$ & $0.53 *$ \\
\hline Teres major & 1 & $0.77^{*}$ & $0.83^{*}$ & $0.31^{*}$ & $0.46^{*}$ & $0.67^{*}$ \\
\hline Teres major & 3 & $0.27^{*}$ & 0.17 & $0.46^{*}$ & $0.27^{*}$ & $0.33^{*}$ \\
\hline Teres major & 6 & $0.47^{*}$ & $0.34^{*}$ & $0.33^{*}$ & $0.22^{*}$ & $0.41 *$ \\
\hline Teres major & 9 & 0.00 & 0.14 & -0.02 & -0.13 & -0.06 \\
\hline Biceps femoris ischiatic head & 0 & $0.89^{*}$ & $0.64^{*}$ & $0.23^{*}$ & $0.41^{*}$ & $0.62 *$ \\
\hline Biceps femoris ischiatic head & 1 & $0.81^{*}$ & $0.91^{*}$ & $0.25^{*}$ & $0.52^{*}$ & $0.71^{*}$ \\
\hline Biceps femoris ischiatic head & 3 & $0.40^{*}$ & $0.20^{*}$ & $0.60^{*}$ & $0.58^{*}$ & $0.50^{*}$ \\
\hline Biceps femoris ischiatic head & 6 & $0.62^{*}$ & $0.53^{*}$ & $0.58^{*}$ & $0.72^{*}$ & $0.83^{*}$ \\
\hline Biceps femoris ischiatic head & 9 & $0.61^{*}$ & $0.62^{*}$ & $0.20^{*}$ & $0.27^{*}$ & $0.52^{*}$ \\
\hline Biceps femoris sirloin cap & 0 & $0.90^{*}$ & $0.66^{*}$ & $0.25^{*}$ & $0.43^{*}$ & $0.60^{*}$ \\
\hline Biceps femoris sirloin cap & 1 & $0.78^{*}$ & $0.90^{*}$ & $0.33^{*}$ & $0.55^{*}$ & $0.73^{*}$ \\
\hline Biceps femoris sirloin cap & 3 & $0.41^{*}$ & $0.37^{*}$ & $0.58^{*}$ & $0.59^{*}$ & $0.74^{*}$ \\
\hline
\end{tabular}


Table 12 (Continued). Pearson correlation coefficients between hue angle values of longissimus lumborum steaks and steaks from 13 beef muscles measured on d $0,1,3,6$, and 9 of display

\begin{tabular}{|c|c|c|c|c|c|c|}
\hline Muscle & Day & Day 0 & Day 1 & Day 3 & Day 6 & Day 9 \\
\hline Biceps femoris sirloin cap & 9 & 0.10 & $0.33^{*}$ & 0.00 & -0.10 & 0.04 \\
\hline Gracillus & 0 & $0.87^{*}$ & $0.59^{*}$ & $0.26^{*}$ & $0.40^{*}$ & $0.62^{*}$ \\
\hline Gracillus & 1 & $0.82^{*}$ & $0.89^{*}$ & $0.28^{*}$ & $0.49^{*}$ & $0.70^{*}$ \\
\hline Gracillus & 9 & $0.48^{*}$ & $0.49^{*}$ & $0.23^{*}$ & 0.19 & $0.38^{*}$ \\
\hline
\end{tabular}

${ }^{*} P<0.05$.

change of LL on d 9 were compared with color change that had occurred in the other muscles included in this study on d 1,3,6, or 9 of display, all of the muscles had correlation coefficients greater than 0.40 at some point during display. However, the day of display associated with the greatest correlation coefficient was muscle dependent. Semimembranosus and GM muscle $\mathrm{pH}$ was moderately correlated with muscle $\mathrm{pH}$ in $\mathrm{LL}$ (Table 14). However, $\mathrm{pH}$ of $\mathrm{BF}$ and $\mathrm{TB}$ steaks was not correlated with $\mathrm{pH}$ of LL steaks. Myoglobin content of SM, BF, GM, and TB steaks was highly $(P<0.05)$ correlated with myoglobin content in LL steaks.

It is notable that for the color attributes evaluated, all were positively correlated between LL and all of the muscles included in the study both on d 0 and again on d 6 or 9 . The moderate to high magnitude of the correlation coefficients describing these relationships indicated that much of the animal variation previously reported in studies on LL steaks also affects other muscles in the carcass. Muscle effects clearly caused some muscles to have a very short color-life (i.e., BFSC), whereas others had relatively long color-life (i.e., LL), but animal differences clearly influenced the rate of change within each of the muscles. Hood (1980) reported that metmyoglobin formation after $4 \mathrm{~d}$ was positively correlated between LM, psoas major, GM, and SM ( $\mathrm{r}=0.38$ to $0.51)$.

\section{Contribution to Variance}

Estimates for variance components of color traits and overall color change are presented in Tables 15 and 16 . The proportion of variance explained by animal and muscle effects was similar across days of display. Animal effects explained approximately one-third of the variance in muscle lightness on each of the display days evaluated in this study. Muscle effects explained approximately another 20 to $30 \%$ of the variance in $\mathrm{L}^{*}$. Muscle effects explained more of the variation in $a^{*}$ values than did animal effects, particularly on d 0,1 , and 3 of display. The relative contribution of animal effects to variance in a* increased as display continued, with animal effects explaining a slightly larger portion of d $9 \mathrm{a}^{*}$ variance than muscle effects. Muscle effects accounted for approximately 5 times as much variation in $\mathrm{b}^{*}$ values than animal effects on $\mathrm{d} 1,3$, and 6 . On $\mathrm{d} 9$, the proportion of $\mathrm{b}^{*}$ variation attributable to muscle effects decreased, which coincided with a sizable increase in the proportion of variance associated with selection day.

Relationships detected for hue angle were similar to those detected for $a^{*}$ values with muscle effects accounting for more than twice as much variation as animal effects on d $0,1,3$, and 6 . However, on d 9, animal effects accounted for twice as much of the variation in hue angle compared with muscle effects. Animal effects were less important than muscle effects in describing variation in color intensity. The proportion of variation in chroma explained by animal effects decreased between $\mathrm{d} 0$ and 1 and then increased between $\mathrm{d} 1$ and 9 to a point that was approximately equal to d 0 values. Overall color change was influenced by both muscle and animal effects, with muscle effects having greater influence on all days of display. The estimates of the contribution of animal effects to variance in color change increased between d 1 and 6 of display and decreased between d 6 and 9 . The contribution of muscle effects to variance in color change increased between $\mathrm{d} 1$ and 3 and then decreased between $\mathrm{d} 3$ and 9 to a point that the relative contributions of animal and muscle effects were similar on d 9 of display.

Quality grade did not contribute to variance to any appreciable degree for any of the traits examined in this experiment. This is in contrast to the results of Correale et al. (1986), who reported that US Prime loin steaks had less surface discoloration than US Good (now called US Select) steaks when stored in the dark for $6 \mathrm{~d}$ in polyvinyl chloride overwrap packaging. King et al. (2010) reported that breed differences in LM lean color stability were inversely related to differences among the same breeds in marbling score and suggested that muscles with less marbling may have greater ability to maintain reducing activity.

A substantial amount of variation is attributed to sample day or unexplained sources. The carcasses sampled for this study were selected from the mill-run production of a commercial processing facility across numerous production lots from multiple suppliers. The 
Table 13. Pearson correlation coefficients between overall color change from d $0(\Delta \mathrm{E})$ values of longissimus lumborum steaks and steaks from 13 beef muscles measured on d 1,3,6, and 9 of display

\begin{tabular}{|c|c|c|c|c|c|}
\hline \multirow[b]{2}{*}{ Muscle } & \multirow[b]{2}{*}{ Day } & \multicolumn{4}{|c|}{ Longissimus lumborum } \\
\hline & & Day 1 & Day 3 & Day 6 & Day 9 \\
\hline Longissimus lumborum & 3 & $0.46^{*}$ & - & - & - \\
\hline Longissimus lumborum & 6 & -0.15 & $0.42^{*}$ & - & - \\
\hline Longissimus lumborum & 9 & $-0.26^{*}$ & $0.20^{*}$ & $0.69^{*}$ & - \\
\hline Semimembranosus & 1 & 0.07 & $0.20^{*}$ & $0.21^{*}$ & 0.14 \\
\hline Semimembranosus & 3 & -0.08 & $0.30^{*}$ & $0.45^{*}$ & $0.64^{*}$ \\
\hline Semimembranosus & 6 & -0.08 & $0.31^{*}$ & $0.56^{*}$ & $0.74^{*}$ \\
\hline Semimembranosus & 9 & $-0.21^{*}$ & 0.09 & $0.52^{*}$ & $0.73^{*}$ \\
\hline Biceps femoris & 1 & $-0.17^{*}$ & $0.26^{*}$ & $0.58^{*}$ & $0.54^{*}$ \\
\hline Biceps femoris & 3 & -0.15 & $0.27^{*}$ & $0.54^{*}$ & $0.69^{*}$ \\
\hline Biceps femoris & 6 & $-0.21^{*}$ & 0.17 & $0.57^{*}$ & $0.72 *$ \\
\hline Biceps femoris & 9 & -0.17 & 0.00 & $0.38^{*}$ & $0.56^{*}$ \\
\hline Gluteus medius & 1 & -0.13 & $0.23^{*}$ & $0.28^{*}$ & $0.25^{*}$ \\
\hline Gluteus medius & 3 & -0.09 & $0.28^{*}$ & $0.50^{*}$ & $0.61 *$ \\
\hline Gluteus medius & 6 & -0.15 & $0.22^{*}$ & $0.58^{*}$ & $0.68^{*}$ \\
\hline Gluteus medius & 9 & $-0.26^{*}$ & -0.05 & $0.41^{*}$ & $0.58^{*}$ \\
\hline Triceps brachii & 1 & -0.01 & $0.27^{*}$ & $0.34^{*}$ & $0.21 *$ \\
\hline Triceps brachii & 3 & -0.09 & $0.20^{*}$ & $0.32^{*}$ & $0.43^{*}$ \\
\hline Triceps brachii & 6 & $-0.25^{*}$ & $0.22^{*}$ & $0.63^{*}$ & $0.70^{*}$ \\
\hline Triceps brachii & 9 & $-0.20^{*}$ & 0.02 & $0.25^{*}$ & $0.57^{*}$ \\
\hline Rectus femoris & 1 & -0.13 & $0.22^{*}$ & $0.36^{*}$ & $0.21^{*}$ \\
\hline Rectus femoris & 3 & -0.14 & 0.21 & $0.46^{*}$ & $0.55^{*}$ \\
\hline Rectus femoris & 6 & -0.14 & 0.17 & $0.51^{*}$ & $0.58^{*}$ \\
\hline Rectus femoris & 9 & -0.07 & 0.04 & 0.16 & $0.36^{*}$ \\
\hline Vastus lateralis & 1 & -0.19 & $0.25^{*}$ & $0.43^{*}$ & $0.43^{*}$ \\
\hline Vastus lateralis & 3 & -0.10 & $0.25^{*}$ & $0.46^{*}$ & $0.60^{*}$ \\
\hline Vastus lateralis & 6 & -0.19 & 0.06 & $0.50^{*}$ & $0.69^{*}$ \\
\hline Vastus lateralis & 9 & -0.05 & 0.00 & 0.02 & $0.21 *$ \\
\hline Adductor & 1 & 0.09 & 0.14 & 0.01 & -0.08 \\
\hline Adductor & 3 & 0.01 & $0.27^{*}$ & $0.42^{*}$ & $0.56^{*}$ \\
\hline Adductor & 6 & -0.15 & 0.17 & $0.59^{*}$ & $0.74^{*}$ \\
\hline Adductor & 9 & -0.12 & 0.04 & $0.28^{*}$ & $0.60^{*}$ \\
\hline Semitendinosus & 1 & 0.02 & -0.03 & 0.00 & -0.19 \\
\hline Semitendinosus & 3 & -0.01 & $0.31^{*}$ & $0.27^{*}$ & $0.30^{*}$ \\
\hline Semitendinosus & 6 & -0.11 & $0.31^{*}$ & $0.58^{*}$ & $0.65^{*}$ \\
\hline Semitendinosus & 9 & -0.18 & 0.15 & $0.53^{*}$ & $0.77^{*}$ \\
\hline Infraspinatus & 1 & $0.16^{*}$ & $0.29^{*}$ & 0.07 & 0.06 \\
\hline Infraspinatus & 3 & 0.05 & 0.09 & 0.01 & -0.01 \\
\hline Infraspinatus & 6 & -0.15 & $0.20^{*}$ & $0.39^{*}$ & $0.40^{*}$ \\
\hline Infraspinatus & 9 & -0.13 & -0.08 & -0.16 & -0.07 \\
\hline Teres major & 1 & -0.05 & 0.16 & 0.04 & 0.07 \\
\hline Teres major & 3 & 0.01 & $0.36^{*}$ & $0.25^{*}$ & $0.30 *$ \\
\hline Teres major & 6 & -0.10 & $0.24^{*}$ & $0.27^{*}$ & $0.45^{*}$ \\
\hline Teres major & 9 & 0.06 & 0.17 & -0.16 & -0.13 \\
\hline Biceps femoris ischiatic head & 1 & $0.24^{*}$ & 0.10 & -0.17 & $-0.21^{*}$ \\
\hline Biceps femoris ischiatic head & 3 & 0.14 & $0.42^{*}$ & $0.27^{*}$ & 0.10 \\
\hline Biceps femoris ischiatic head & 6 & -0.18 & 0.18 & $0.72^{*}$ & $0.76^{*}$ \\
\hline Biceps femoris ischiatic head & 9 & -0.11 & 0.04 & $0.23^{*}$ & $0.48^{*}$ \\
\hline Biceps femoris sirloin cap & 1 & -0.17 & $0.27^{*}$ & $0.53^{*}$ & $0.53^{*}$ \\
\hline Biceps femoris sirloin cap & 3 & -0.19 & $0.26^{*}$ & $0.57^{*}$ & $0.74 *$ \\
\hline Biceps femoris sirloin cap & 6 & $-0.23^{*}$ & -0.02 & $0.33^{*}$ & $0.54^{*}$ \\
\hline Biceps femoris sirloin cap & 9 & 0.00 & -0.05 & $-0.21^{*}$ & -0.15 \\
\hline Gracillus & 1 & 0.02 & 0.13 & 0.09 & 0.00 \\
\hline Gracillus & 3 & 0.02 & $0.22^{*}$ & $0.36^{*}$ & $0.39 *$ \\
\hline Gracillus & 6 & -0.14 & 0.12 & $0.40^{*}$ & $0.61 *$ \\
\hline Gracillus & 9 & 0.08 & 0.06 & -0.05 & 0.07 \\
\hline
\end{tabular}

$* P<0.05$.

genetic and management background of the cattle producing these carcasses is not known, but likely differed considerably across the selection days. It is known that genetics and antemortem management influence color stability (Faustman and Cassens, 1990; King et al., 2010). Furthermore, the chilling conditions are known 
Table 14. Pearson correlation coefficients for myoglobin concentration and $\mathrm{pH}$ values between longissimus lumborum steaks and steaks from 4 beef muscles

\begin{tabular}{llc}
\hline \hline Muscle & $\mathrm{pH}$ & Myoglobin \\
\hline Semimembranosus & $0.44^{*}$ & $0.83^{*}$ \\
Biceps femoris & 0.07 & $0.82^{*}$ \\
Gluteus medius & $0.53^{*}$ & $0.72^{*}$ \\
Triceps brachii & 0.18 & $0.67^{*}$ \\
\hline
\end{tabular}

$* P<0.05$.

to vary across and within coolers in processing plants and are further influenced by factors such as carcass spacing and carcass fatness, which also would influence color stability (Ledward, 1985; Sammel et al., 2002; Seyfert et al., 2006). Thus, the large amount of variance attributable to selection day and unknown factors in this study is likely representative of multiple influences present in large-scale beef production. Furthermore, some of the variation attributed to sampling day may actually be due to differences in the animals processed on those days.

The present experiment suggests that animal effects contribute to the variation in color and color stabil- ity across animals, but that contribution is less than the direct effects causing differences across muscles. As discussed above, muscle effects are mediated through gross differences in histochemical properties. Such effects would be expected to be larger than the comparatively subtle differences observed in homologous muscles across animals. Animal effects seem to have a greater relative contribution to color traits later in the display period. Previous work from our laboratory has identified substantial variation in LL color stability across animals, which is genetically regulated (King et al., 2010). In that experiment, heritability and breed effects were greater for the values of color variables measured on d 6 of display and for the change in the values between $\mathrm{d} 0$ and 6 of display than the values of the same variables measured on d 0 of display. Furthermore, metmyoglobin reducing activity was slightly more highly correlated with color change when measured at the end rather than the beginning of display (King et al., 2011). Thus, evidence suggests that meaningful differences in color stability across animals exist in commercial beef production.

Hood (1980) and Renerre and Labas (1987) reported variance component estimates that are remarkably consistent with the results of the present experiment.

Table 15. Variance components of color and color stability attributes of steaks from 14 beef muscles placed in simulated retail display for $9 \mathrm{~d}^{1}$

\begin{tabular}{|c|c|c|c|c|c|c|}
\hline \multirow{2}{*}{$\begin{array}{l}\text { Variance } \\
\text { component }\end{array}$} & \multicolumn{2}{|c|}{$\mathrm{L}^{*}$} & \multicolumn{2}{|c|}{$a^{*}$} & \multicolumn{2}{|c|}{$\mathrm{b}^{*}$} \\
\hline & Estimate & Percentage & Estimate & Percentage & Estimate & Percentage \\
\hline Selection day & 0.42 & 2.13 & 0.10 & 1.19 & 3.19 & 24.64 \\
\hline Quality grade & 0.00 & 0.00 & 0.00 & 0.00 & 0.00 & 0.00 \\
\hline Animal & 6.63 & 33.37 & 1.22 & 14.31 & 1.72 & 13.30 \\
\hline \multicolumn{7}{|l|}{ Day 1} \\
\hline Selection day & 2.28 & 10.91 & 0.69 & 9.42 & 4.32 & 38.72 \\
\hline Quality grade & 0.00 & 0.00 & 0.00 & 0.03 & 0.00 & 0.00 \\
\hline Animal & 6.89 & 32.95 & 0.45 & 6.15 & 0.51 & 4.58 \\
\hline Muscle & 4.23 & 20.23 & 2.53 & 34.42 & 2.88 & 25.81 \\
\hline Residual & 7.51 & 35.91 & 3.67 & 49.98 & 3.44 & 30.88 \\
\hline Residual & 8.28 & 38.71 & 5.12 & 33.18 & 3.04 & 45.14 \\
\hline \multicolumn{7}{|l|}{ Day 6} \\
\hline Selection day & 0.00 & 0.00 & 10.48 & 23.10 & 0.74 & 8.83 \\
\hline Quality grade & 0.00 & 0.00 & 0.00 & 0.00 & 0.00 & 0.00 \\
\hline Animal & 7.80 & 34.69 & 7.21 & 15.89 & 0.76 & 9.03 \\
\hline Muscle & 6.05 & 26.94 & 16.64 & 36.66 & 3.59 & 42.85 \\
\hline Residual & 8.62 & 38.37 & 11.05 & 24.35 & 3.29 & 39.28 \\
\hline \multicolumn{7}{|l|}{ Day 9} \\
\hline Selection day & 0.75 & 2.73 & 2.52 & 9.44 & 2.70 & 27.14 \\
\hline Quality grade & 0.00 & 0.00 & 0.18 & 0.68 & 0.00 & 0.00 \\
\hline Animal & 8.73 & 31.95 & 5.68 & 21.28 & 0.88 & 8.82 \\
\hline Muscle & 7.71 & 28.23 & 4.93 & 18.48 & 2.69 & 27.00 \\
\hline
\end{tabular}

${ }^{1} \mathrm{~L}^{*}=$ lightness; $\mathrm{a}^{*}=$ redness; $\mathrm{b}^{*}=$ yellowness. 
Table 16. Variance components of color and color stability attributes of steaks from 14 beef muscles placed in simulated retail display for $9 \mathrm{~d}$

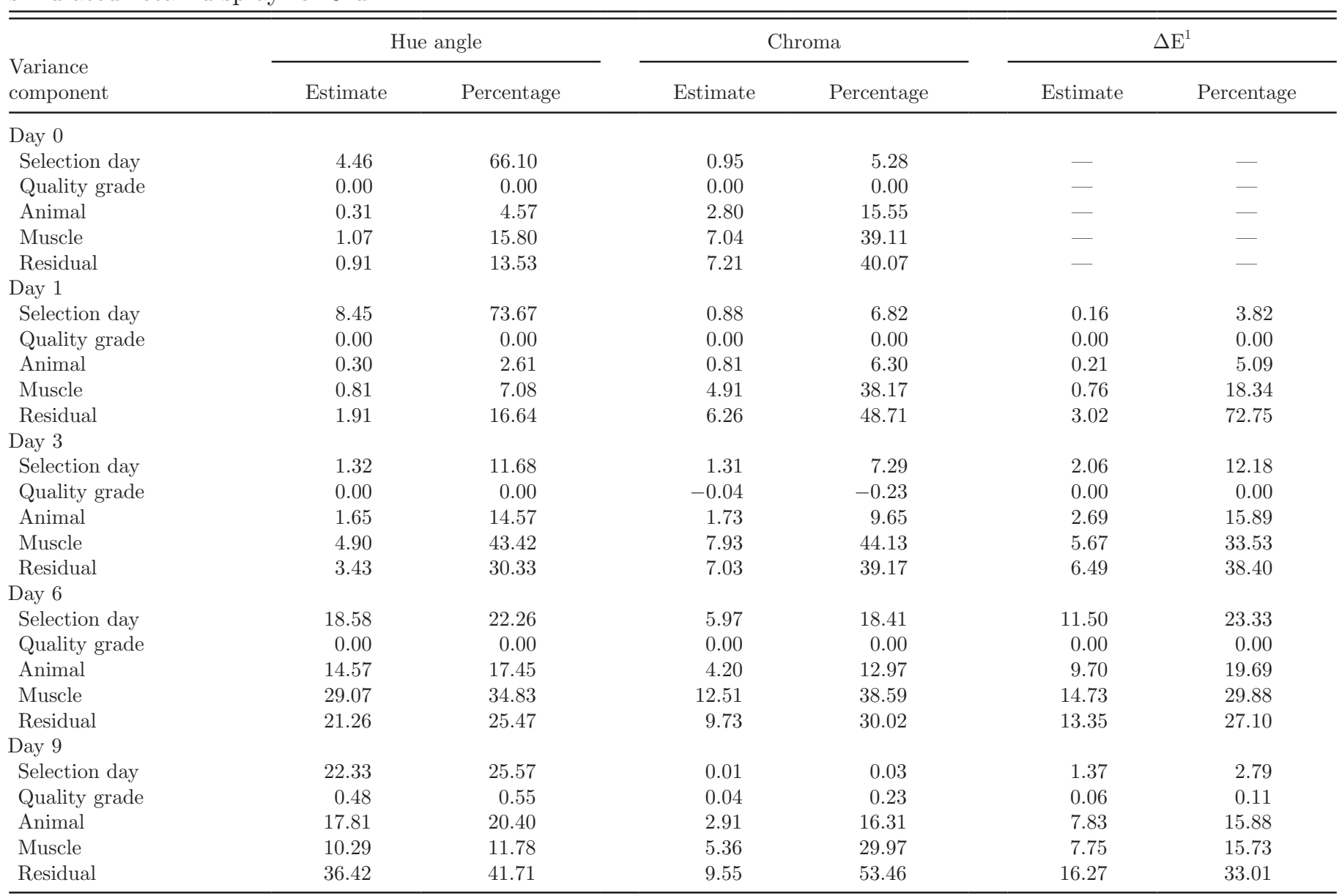

${ }^{1} \Delta \mathrm{E}=$ overall color change from d 0.

However, despite statistical significance of animal effects, both of those investigators concluded that animal variation in color stability was less important in comparison with the influence of muscle effects. However, the evidence indicates that animal effects consistently explain variation in color stability in the hands of multiple investigators, which highlights its importance as a factor influencing color stability. Furthermore, correlation analyses indicate that interanimal variation is remarkably consistent across the muscles within the carcass, and its relative importance increased as display progressed.

The results of this experiment indicate that interanimal variation contributed to variation in beef lean color stability, though that contribution was smaller than muscle effects within the carcass. Although large differences in initial color and in the extent and timing of discoloration existed across muscles within a carcass, the high degree of correlation across muscles indicated that the influence of animal effects was consistent across muscles. The most practical implication of this finding is that technology or strategies designed to improve lean color stability of LL steaks would have a simultaneous effect on other muscles in the carcass.

\section{LITERATURE CITED}

Bekhit, A. E. D., and C. Faustman. 2005. Metmyoglobin reducing activity. Meat Sci. 71:407-439.

Bendall, J. R. 1973. Postmortem changes in muscle. Pages 243-309 in Structure and Function of Muscle. Vol. 2. G. H. Bourne, ed. Academic Press, New York, NY.

Correale, K. K., J. W. Savell, D. B. Griffin, G. R. Acuff, and C. Vanderzant. 1986. Microbiological and sensory characteristics of beef loin steaks: Role of intramuscular fat. Meat Sci. $18: 161-172$.

Faustman, C., and R. G. Cassens. 1990. The biochemical basis for discoloration in fresh meat: A review. J. Muscle Foods 1:217243.

Faustman, C., and R. G. Cassens. 1991. The effect of cattle breed and muscle type on discoloration and various biochemical parameters in fresh beef. J. Anim. Sci. 69:184-193.

Hood, D. E. 1980. Factors affecting the rate of metmyoglobin accumulation in pre-packaged beef. Meat Sci. 4:247-265.

Hunt, M. C., and H. B. Hedrick. 1977. Profile of fiber types and related properties of five bovine muscles. J. Food Sci. 42:513517.

Hunt, M. C., O. Sørheim, and E. Slinde. 1999. Color and heat denaturation of myoglobin forms in ground beef. J. Food Sci. 64:847-851.

King, D. A., S. D. Shackelford, L. A. Kuehn, C. M. Kemp, A. B. Rodriguez, R. M. Thallman, and T. L. Wheeler. 2010. Contribution of genetic influences to animal-to-animal variation in 
myoglobin concentration and beef lean color stability. J. Anim. Sci. 88:1160-1167.

King, D. A., S. D. Shackelford, A. B. Rodriguez, and T. L. Wheeler. 2011. Effect of time of measurement on the relationship between metmyoblobin reducing activity and oxygen consumption to instrumental measures of color stability. Meat Sci. 87:26-32.

Klont, R. E., L. Brocks, and G. Eikelenboom. 1998. Muscle fibre type and meat quality. Meat Sci. 49:S219-S229.

Lanari, M. C., and R. G. Cassens. 1991. Mitochondrial activity and beef muscle color stability. J. Food Sci. 56:1476-1479.

Lawrence, T. E., M. E. Dikeman, M. C. Hunt, C. L. Kastner, and D. E. Johnson. 2004. Effects of enhancing beef longissimus with phosphate plus salt, or calcium lactate plus non-phosphate water binders plus rosemary extract. Meat Sci. 67:129-137.

Ledward, D. A. 1985. Post-slaughter influence on the formation of metmyoglobin in beef muscles. Meat Sci. 15:149-171.

Mancini, R. A., and M. C. Hunt. 2005. Current research in meat color: 51st International Congress of Meat Sci. and Technology (ICoMST). Meat Sci. 71:100-121.

Mancini, R. A., M. Seyfert, and M. C. Hunt. 2008. Effects of data expression, sample location, and oxygen partial pressure on initial nitric oxide metmyoglobin formation and metmyoglobinreducing-activity measurement in beef muscle. Meat Sci. 79:244-251.

May, M. L., M. E. Dikeman, and R. Schalles. 1977. Longissimus muscle histological characteristics of Simmental $\times$ Angus, Hereford $\times$ Angus, and Limousin $\times$ Angus crossbred steers as related to carcass composition and meat palatability traits. J. Anim. Sci. $44: 571-580$.

McKenna, D. R., P. D. Mies, B. E. Baird, K. D. Pfeiffer, J. W. Ellebracht, and J. W. Savell. 2005. Biochemical and physical factors affecting discoloration characteristics of 19 bovine muscles. Meat Sci. 70:665-682.
NAMP. 2003. Meat Buyers Guide. Natl. Assoc. Meat Purveyors, Reston, VA.

O'Keefe, M., and D. E. Hood. 1982. Biochemical factors influencing metmyoglobin formation on beef from muscles of differing colour stability. Meat Sci. 7:209-228.

Renerre, M., and R. Labas. 1987. Biochemical factors influencing metmyoglobin formation in beef muscles. Meat Sci. 19:151165.

Sammel, L. M., M. C. Hunt, D. H. Kropf, K. A. Hachmeister, C. L. Kastner, and D. E. Johnson. 2002. Influence of chemical characteristics of beef inside and outside semimembranosus on color traits. J. Food Sci. 67:1323-1330.

Seyfert, M., R. A. Mancini, M. C. Hunt, J. Tang, C. Faustman, and M. Garcia. 2006. Color stability, reducing activity, and cytochrome $\mathrm{C}$ oxidase activity of five bovine muscles. J. Agric. Food Chem. 54:8919-8925.

Shackelford, S. D., T. L. Wheeler, and M. Koohmaraie. 2005. Online classification of US Select beef carcasses for longissimus tenderness using visible and near-infrared reflectance spectroscopy. Meat Sci. 69:409-415.

Talmant, A., and G. Monin. 1986. Activities of metabolic and contractile enzymes in 18 bovine muscles. Meat Sci. 18:23-40.

USDA. 1996. IMPS 100 Fresh Beef-PDF version. USDA Agricultural Marketing Service. Accessed Jul. 16, 2009. http://www. ams.usda.gov/lsg/imps/imps100.pdf.

Vestergaard, M., N. Oksbjerg, and P. Henckel. 2000. Influence of feeding intensity, grazing and finishing feeding on muscle fibre characteristics and meat colour of semitendinosus, longissimus dorsi and supraspinatus muscles of young bulls. Meat Sci. 54:177-185.

Warriss, P. D. 1979. The extraction of haem pigments from fresh meat. J. Food Technol. 14:75-80. 
References

This article cites 25 articles, 3 of which you can access for free at: http://jas.fass.org/cgi/content/full/89/5/1434\#BIBL 